\title{
Timing and composition of continental volcanism at Harrat Hutaymah,
} western Saudi Arabia

Robert A. Duncan ${ }^{1,2}$, Adam J.R. Kent ${ }^{1}$, Carl R. Thornber ${ }^{3}$, Tyler D. Schlieder ${ }^{1}$, and Abdullah M. Al-Amri ${ }^{2}$

${ }^{1}$ College of Earth, Ocean, and Atmospheric Sciences, Oregon State University, Corvallis, OR 97333 USA

${ }^{2}$ Department of Geology and Geophysics, King Saud University, Riyadh, KSA

${ }^{3}$ U.S. Geological Survey, Cascades Volcano Observatory, Vancouver, WA USA

$\underline{\text { Abstract }}$

Harrat Hutaymah is an alkali basalt volcanic field in north-central Saudi Arabia, at the eastern margin of a large Neogene continental, intraplate magmatic province. Lava flow, tephra and spatter cone compositions in the field include alkali olivine basalts and basanites. These compositions contrast with the predominantly tholeiitic, fissure-fed basalts found along the eastern margin of the Red Sea. The Hutaymah lava flows were erupted through Proterozoic arc-associated plutonic and meta-sedimentary rocks of the Arabian shield, and commonly contain a range of sub-continental lithospheric xenoliths, although the lavas themselves show little indication of crustal contamination. Previous radiometric dating of this volcanic field (a single published $\mathrm{K}-\mathrm{Ar}$ age; $1.8 \mathrm{Ma}$ ) is suspiciously old given the field measurement of normal magnetic polarity only (i.e. Brunhes interval, $\leq 780 \mathrm{Ka}$ ). We report new age determinations on 14 lava flows by the ${ }^{40} \mathrm{Ar}-{ }^{39} \mathrm{Ar}$ laser step heating method, all younger than $\sim 850 \mathrm{Ka}$, to better constrain the time frame of volcanism, and major, trace and rare earth element compositions to describe the chemical variation of volcanic activity at Harrat Hutaymah. Crystal fractionation was dominated by olivine \pm clinopyroxene at a range of upper mantle and crustal pressures. Rapid ascent and eruption of magma is indicated by the array of lower 
31 crustal and lithospheric xenoliths observed in lava flows and tephra. Modeling suggests

$32 \quad 1-7 \%$ melting of an enriched asthenospheric mantle source occurred beneath Harrat

33 Hutaymah under a relatively thick lithospheric cap $(60-80 \mathrm{~km})$.

34 


\section{1. Introduction}

\section{The Harrat Province}

37 One of the largest alkali basalt provinces in the world (area: $180,000 \mathrm{~km}^{2}$ ) is

38 located in the western part of the Arabian Peninsula (Figure 1). These extensive Cenozoic

39 basaltic lava fields (in Arabic "harrats") erupted predominantly from N-S oriented

40 volcanic centers that lie within $500 \mathrm{~km}$ of the NW-trending eastern margin of the Red Sea.

41 The origin of these fields appears to be related to regional extension and thinning of thick,

42 Arabian-Nubian Pan-African craton that began 30 Ma (Coleman, 1993; Camp and

43 Roobol, 1992). Curiously, there is no equivalent of this volcanic activity in eastern Egypt

44 and Sudan, on the opposite side of Africa-Arabia plate separation (Bohannon et al., 1989).

45 In contrast with tholeiitic basalts of the Red Sea spreading system, lava compositions in

46 the region of the harrats include alkali olivine basalts, olivine-transitional basalts, and

47 hawaiites, with minor more evolved compositions. Early volcanism ( $>12 \mathrm{Ma})$, aligned

48 with the NW orientation of the opening Red Sea, was dominated by tholeiitic to

49 transitional compositions, but since then compositions have become more alkalic, and

50 erupted from younger, more broadly distributed N-S oriented volcanic centers $(<12 \mathrm{Ma})$.

51 A prominent N-S alignment of relatively large volume volcanic fields, the Makkah-

52 Madinah-Nafud (MMN) line, coincides with the Ha'il Arch, a structural axis of uplift of

53 the Arabian shield, beginning $~ 15$ Ma.

54

\section{$55 \quad$ Harrat Hutaymah}

56 Harrat Hutaymah (Figure 2), one of the smallest and youngest harrats, assembled

57 from monogenetic cones and lava flows covering $\sim 900 \mathrm{~km}^{2}$, is also the easternmost harrat, 
$58 \sim 500 \mathrm{~km}$ from the Red Sea axis (Thornber, 1992). Previous work at Hutaymah, which

59 includes geochemical and petrologic studies, and K-Ar age determinations (Thornber,

60 1992; Pallister, 1984), reveals that Harrat Hutaymah is dominated by a compositionally

61 narrow range of alkaline basalts, from basanite to trachy-basalt, that erupted from 15

62 main centers. Compared to other Arabian harrats, Hutaymah presents an unusual

63 abundance of explosive volcanism and crust- and mantle-derived xenolithic material,

64 including igneous pyroxenite, melt-bearing peridotite and metamorphic pyroxenite

65 (Thornber, 1992). Previous models for the petrogenesis of Harrat Hutaymah, and the

66 harrat province as a whole, attribute the volcanism to decompression melting of mantle

67 upwelling in response to plate thinning and separation along the eastern flank of the Red

68 Sea Rift (Hempton, 1987; Coleman and McGuire, 1988; Pallister, 1987).

69 A recent study of Harrat Lunayyir, located west of Harrat Hutaymah, suggests

70 that some previous K-Ar ages reported for many harrats may be inaccurate because of the

71 common occurrence of xenolithic fragments that carry 'excess' (undegassed, non-

72 atmospheric) argon (Duncan and Al-Amri, 2013). Variation in major and trace element

73 compositions of erupted lavas throughout the harrat province appear the reflect

74 differences in depth and degree of melting of either lithospheric mantle or asthenosphere

75 (or both), in response to the tectonic thinning (Camp and Roobol, 1991; Duncan and Al-

76 Amri, 2013). An additional consideration is the possible influence of asthenospheric flow

77 from the Afar plume, which may be channeling warm mantle beneath the Arabian shield

78 (Camp and Roobol, 1991; Chang and Van der Lee, 2011).

79 The location of Harrat Hutaymah on the eastern edge of the harrat province, the

80 extensive geochemical work produced by Thornber (1992), and the uncertain reported K- 
81 Ar ages make Hutaymah an ideal location to add information about the timing and

82 compositions of volcanic activity, with new age determinations using high precision ${ }^{40} \mathrm{Ar}-$

$83{ }^{39}$ Ar laser step heating experiments, and further geochemical data. Our new results are

84 compared with previous data from Harrat Lunayyir (Duncan and Al-Amri, 2013), Harrat

85 Rahat (Camp and Roobol, 1989; Moufti et al., 2013), and the Red Sea (e.g. Kelley et al.

86 2013, Vlastelic et al., 1998) to map the regional trends in lava composition in time and

87 location. We conclude that Hutaymah volcanism is the result of decompression melting

88 of subcontinental lithosphere and asthenosphere (60-80 $\mathrm{km}$ depth), in response to

89 regional extension and/or thermal erosion by northward asthenospheric flow from the

90 Afar hot spot.

91

92

93

\section{$\underline{\text { Volcanology }}$}

94 Harrat Hutaymah volcanism is restricted to a narrow range of alkaline mafic lava

95 compositions that cover a relatively small area $\left(\sim 900 \mathrm{~km}^{2}\right)$ compared to other Arabian

96 harrats (Thornber, 1992). The name derives from one of the most prominent volcanic

97 centers in the area, Al Hutaymah, a large $\sim 1 \mathrm{~km}$ diameter, $300 \mathrm{~m}$ deep tuff ring (maar),

98 located in the west central area of the volcanic field (Bramkamp et al., 1963; Thornber,

99 1992). Al Hutaymah is one of 15 main eruptive centers within this volcanic field. In

100 addition to large craters, the Hutaymah volcanic field presents an unusual abundance of

101 tuff rings (maars), indicating explosive activity resulting from interactions between

102 magma and water, i.e., phreatomagmatic style eruptions (Thornber, 1992).

103 The concentration of explosive activity at Hutaymah is reflected in the abundant

104 tephra deposits and variable crater morphology (Thornber, 1992). Isolated maars (craters

105 rimmed by tuff rings) can be found at Al Hutaymah, Tabah, Tamur, An Na'i, and Al 
106 Hamra. Isolated tuff ring rimmed craters that have been largely in-filled by Quaternary

107 alluvium are found at Samra as Safra, Dibadib, Dahrat Humayan, and Dakhana, and with

108 grouped vents of similar morphology at Jabal Dilham, Jabal Um Harruj, Jabal Duwayrah,

109 as Sa, Jabal Al Qufayl, and Saiynin (Figure 2). Commonly, reworked tephra can be found

110 radially distributed from the tuff rings, covering an area of $10-60 \mathrm{~km}^{2}$. Large lava flows

111 up to $60 \mathrm{~km}^{2}$ and $40 \mathrm{~m}$ thick overlie nested tuff rings at Al Jaddu, Al Hamra, and as Sa,

112 and the inverse relationship, tuff-ring tephra superimposed over coherent flows, can be

113 viewed in maar walls at Al Hutaymah and Jabal Iqfah (Thornber, 1992). Approximately

11485 small alkali basaltic cinder/spatter cones $(<1 \mathrm{~km}$ diameter $)$ and fissures $(<1-2 \mathrm{~km}$

115 length) produced scoria and small a'a flows (with minor pahoehoe flows) (Thornber,

116 1992). A defining characteristic of Hutaymah volcanism is the abundance of ultramafic

117 xenoliths and megacrysts distributed throughout the tephra, flows, and spatter cones,

118 likely sourced from the lower crust or upper mantle (Thornber, 1990). Collectively, these

119 isolated and grouped cones, maars, tuff-rings, and elongate fissure eruptions define the

120 eruptive characteristics of the entire harrat (Thornber, 1992).

121 The vents (spatter cones, tuff rings, fissures) are aligned along a series of

122 northerly to north-northeasterly trending lineaments (Pallister, 1984). Individual vent

123 clusters are also elongated in the north-south direction. According to Pallister (1984) this

124 alignment does not conform with the structural fabric of underlying Proterozoic rocks,

125 but indicates a significant shift in orientation of the Quaternary stress field relative to the

126 older crustal structures and relative to the NW-SE trend of the Red Sea axis. 
We examined fifty-seven lava flow samples from Harrat Hutaymah, including a

130 subset of a collection made by one of us as the basis of a $\mathrm{PhD}$ dissertation (5-digit

131 identifiers, Thornber, 1992), and augmented by field work by two of us (HH- identifiers,

132 RAD and AMA) in 2013. We categorized samples in hand sample and thin section, and

133 divided these into groups based on spatial distribution, texture, and mineralogy for dating

134 and geochemical analysis. Samples unsuitable for age determinations based on alteration

135 or xenocrystic inclusions were excluded from further analysis. We selected samples for

136 dating that were aphyric to sparsely phyric, well-crystallized and lacking interstitial glass.

137 We obtained bulk rock major and minor element concentrations (Table 1) for our

138 samples at the GeoAnalytical Laboratory at Washington State University (WSU) using

139 the X-ray fluorescence (XRF) method (Johnson et al., 1999) and selected samples were

140 analyzed for trace element concentrations (Table 2) by inductively coupled plasma source

141 mass spectrometry (ICP-MS; Knack et al., 1994). For analysis a dilithium tetraborate flux

142 was mixed with a portion of the rock powder (2:1 ratio for XRF; 1:1 ratio for ICP-MS) to

143 produce fused beads. Based on replicate analyses the estimated uncertainties (at $\pm 2 \mathrm{~s}$ ) for

$144 \mathrm{XRF}$ major element measurements are $<1 \%$ for all elements. Estimated uncertainties for

145 trace elements $( \pm 2 \mathrm{~s})$ by $\mathrm{XRF}$ are $<80 \%$ for $\mathrm{Pb}$, Th, and $\mathrm{U} ;<40 \%$ for $\mathrm{Rb}, \mathrm{Ce} ;<25 \%$ for

$146 \mathrm{Nb}, \mathrm{La}, \mathrm{Ce}$ and $\mathrm{Nd}$, and $<5 \%$ for all other elements. For trace elements analyses by ICP-

147 MS estimated uncertainties are $<20 \%$ for $\mathrm{U}$ and $\mathrm{Th},<10 \%$ for $\mathrm{Cs}$ and $<5 \%$ (2s) for all

148 other elements (Knack et al., 1994). Further details on precision and detection limits are

149 given in Johnson et al. (1999) and Knack et al. (1994). We also provide major and trace

150 element data (see Supplementary Geochemical Data) for the older collection of samples

151 (Thornber, 1992) using X-ray fluorescence spectrometry and instrumental neutron 
152 activation analysis (INAA) methods (Quick and Hellaby, 1988; Baedecker and McKown,

153 1987). Major element data from the recent collection were derived by X-ray fluorescence

154 (XRF) at the Washington State University Geoanalytical Lab (Table 1). Trace element

155 and rare earth element data were collected using inductively coupled plasma mass

156 spectrometry (ICP-MS) at the Washington State University Geoanalytical Lab (Table 2).

157 We performed age determinations of groundmass separates at Oregon State

158 University with standard ${ }^{40} \mathrm{Ar}-{ }^{39} \mathrm{Ar}$ laser step heating methods. Whole rock samples were

159 crushed, sieved, washed, and subjected to mild acid leaching with $\mathrm{HCl}$ and $\mathrm{HNO}_{3}$ then

160 hand-picked to remove phenocryst phases. Some 100mg of prepared groundmass of each

161 sample was next irradiated for 6 hours in the 1MW TRIGA nuclear reactor at Oregon

162 State University, along with flux monitor FCT sanidine (28.201 Ma; Kuiper et al., 2008).

163 Irradiated samples were loaded into $\mathrm{Cu}$-planchettes in an ultra-high vacuum sample

164 chamber and incrementally heated (in $16-33$ steps, from $400^{\circ} \mathrm{C}$ to fusion) by scanning a

165 defocused $25 \mathrm{~W} \mathrm{CO}_{2}$ laser beam in preset patterns across each sample, in order to release

166 the Ar evenly. Argon isotope compositions of irradiated samples were determined using

167 the Thermo Scientific Model ARGUS VI multi-collector with five fixed Faraday

168 detectors (all fitted with $10^{12} \mathrm{Ohm}$ resisters) and 1 ion-counting $\mathrm{CuBe}$ electron multiplier,

169 allowing simultaneous measurement of all Ar isotopes, with mass 36 on the ion multiplier

170 and masses 37 through 40 on the four adjacent Faraday cups. Gas cleanup occurred in a

171 small-volume, all-metal extraction line equipped with $\mathrm{Zr}$-Al getters. We monitored the

172 atmospheric correction with an air pipette system, and cross-calibrated the 5 collectors

173 for small differences in sensitivity, on a daily basis. We calculated ages (reported at $\pm 2 \square$

174 uncertainty) in several ways (Table 3). Plateau ages are the weighted (by inverse 
175 variance) means of concordant, sequential step ages while isochron ages are derived from

176 regressions of the same heating step isotopic compositions. All calculations were

177 performed using the ArArCALC v2.6.2 software package (Koppers, 2002).

178 We modeled conditions and compositions of parental melt generation and

179 evolution using the MELTS software package (Ghiorso and Sack, 1995). Oxygen

180 fugacity was buffered at the quartz-fayalite-magnetite buffer (QFM). The initial magma

181 composition used in the model is found in Table 4. We estimated this starting

182 composition from the major element variation with respect to $\mathrm{Mg} \#(\mathrm{MgO} /(\mathrm{FeO}+\mathrm{MgO})$

183 in mole percent), inferring likely parental compositions to have $\mathrm{Mg \#}$ of $0.71-0.72$, in

184 equilibrium with olivine of Fo $_{91-93}$ composition (Roeder and Emslie, 1970; Putirka, 2005).

185 This parental composition is very similar to that proposed by Thornber (1992) from an

186 average of 8 most primitive lava compositions (Table 4). MELTS models were run with a

187 small amount of water present $(<0.5 \mathrm{wt} . \%)$. Forward models of the variation in rare earth

188 element (REE) contents during mantle melting were modeled using the MATLAB

189 REEBOX package (Brown and Lesher, 2014) which implements the incremental

190 polybaric non-modal batch melting approach of Fram and Lesher (1992).

191

192 3. Results

193 Petrography

194

195 We examined all samples in thin section. Phenocryst concentration varies from

$196<5 \%$ to $20 \%$, but averages $\sim 10 \%$. Samples are dominantly olivine-phyric to microphyric

197 (90\% olivine) with subhedral to euhedral olivine (0.1 to $3 \mathrm{~mm})$ in an aphanitic

198 groundmass of fine plagioclase laths and interstitial olivine, pyroxene \pm glass. Hexagonal, 
199 rounded, and hopper morphologies are common in olivine, and most crystals are at least 200 partially altered to iddingsite. When possible, forsterite content was estimated using $2 \mathrm{~V}$

201 angle, and ranged from $\mathrm{Fo}_{80}$ to $\mathrm{Fo}_{90}$. Pyroxenes, mainly augite (0.1 to $\left.1 \mathrm{~mm}\right)$, do not

202 exceed $10 \%$ of the total phenocryst population. Plagioclase is typically confined to fine

203 grained laths in the groundmass, but in four samples large (up to $3 \mathrm{~mm}$ ) plagioclase

204 crystals are present. In these cases the plagioclase is highly sieved with large embayments

205 along the rims, and are likely to be xenocrysts. The majority of plagioclase crystals are

206 too fine to determine anorthite content, but in a few moderately large, twinned crystals

207 we estimated the composition from extinction angles to be $\mathrm{An}_{45}$ to $\mathrm{An}_{70}$. Minor opaque

208 minerals, likely spinel $(0.25 \mathrm{~mm})$, are ubiquitous at $<5 \%$. Several samples are diktytaxitic,

209 and less commonly pilotaxitic. Glomerocrysts of large plagioclase phenocrysts occur in

210 some samples (e.g., HH-4), and are associated with quartz xenocrysts. Nearly all samples

211 exhibit an aphanitic glassy groundmass ranging from slightly vesicular to non-vesicular

212 with the exception of sample HH-11 that is almost entirely crystalline.

213 Geochronology

$214 \quad{ }^{40} \mathrm{Ar}-{ }^{39} \mathrm{Ar}$ data obtained for 14 samples are summarized in Table 3. Complete data

215 files for all experiments are available as Supplementary Geochronological Data from the

216 journal. Reliable plateau ages for 10 of these range from 260 to $850 \mathrm{Ka}$. These have

217 corresponding concordant isochron ages with atmospheric ${ }^{40} \mathrm{Ar} /{ }^{36} \mathrm{Ar}$ intercepts. However,

218 clear evidence for excess ${ }^{40} \mathrm{Ar}$, probably derived from undetected xenolithic fragments, is

219 seen in the age spectra for several samples (Figure 3b). For example, the age spectra for

220 samples $176701 \mathrm{~b}$ and 176691 exhibit "saddle-shape" age spectra in which the middle

221 range of temperature steps (those that are most radiogenic) are least affected by 
222 xenolithic outgassing. In these cases, the isochron plots provide consistently younger

223 ages, within the range of the uncomplicated plateau ages, and non-atmospheric ${ }^{40} \mathrm{Ar} /{ }^{36} \mathrm{Ar}$

224 intercepts.

225 In view of the excess ${ }^{40} \mathrm{Ar}$ problem, three samples (176701, 176710 and 176734)

226 were analyzed twice, from separate aliquots. Sample 176701a produced an acceptable

227 plateau $(818 \pm 203 \mathrm{Ka})$ without evidence of excess Ar; however, sample $176701 \mathrm{~b}$

228 (mentioned above) did show excess Ar, and we prefer the isochron age (893 $\pm 44 \mathrm{Ka})$,

229 which is within error of the 176701a plateau age. Sample 176710a showed a disturbed

230 age spectrum, with decreasing and irregular step ages with temperature, from which no

231 credible isochron developed. The second analysis (176710b) produced a saddle-shaped

232 age sprectrum with a well-defined middle temperature plateau $(848 \pm 8 \mathrm{Ka})$, and a

233 corresponding isochron age of $838 \pm 44 \mathrm{Ka}$. Sample $176734 \mathrm{a}$ showed a simple plateau at

$234868 \pm 90 \mathrm{ka}$, while the second analysis (176734b) exhibited a small effect from excess Ar

235 but a reliable plateau at $804 \pm 10 \mathrm{Ka}$. These new ages are generally younger than, and

236 considerably less variable than previous $\mathrm{K} / \mathrm{Ar}$ ages $(0.1$ to $2.65 \mathrm{Ma}$, Thornber, $1992 ; 1.84$

$237 \pm 0.05$ Ma, Pallister, 1984).

238 Geochemistry

239

240

Major, trace, and rare earth element concentrations for 10 new samples are

241 reported in Table 1 and Table 2, respectively, and previously analyzed but unpublished

242 compositions for 49 lavas and tephras from Thornber (1992) are given in the

243 Supplementary Geochemical Data. A total alkalis vs. silica diagram comparing the Harrat

244 Hutaymah lavas with selected other harrats and Red Sea lavas (Figure 4) demonstrates

245 that the new Harrat Hutaymah data agree well with those from Thornber (1992). 
246 Hutaymah lavas exhibit a small range of compositional variation, from basanite to alkali

247 basalt (44 to $49 \mathrm{wt} \% \mathrm{SiO}_{2}$ and 3.6 to $6.4 \mathrm{wt} \% \mathrm{Na}_{2} \mathrm{O}+\mathrm{K}_{2} \mathrm{O}$ ), and trachy-basalt (hawaiite).

$248 \mathrm{Mg \#}$ is restricted to the range $0.53-0.73$ and $\mathrm{MgO}$ contents from $\sim 7-14$ wt.\% $\mathrm{MgO}$,

249 indicating rather primitive, unevolved compositions. This aligns with the petrographic

250 observation of olivine \pm clinopyroxene dominated crystallization. The limited

251 compositional range at Hutaymah and the restriction to less evolved compositions is

252 similar to Harrat Lunayyir, which is also located off the MMN line axis (Figure 1;

253 Duncan and Al-Amri 2013), whereas lavas from the larger and centrally located harrats

254 (e.g., Rahat, Khaybar) show greater variation and extend to more evolved compositions

255 (Moufti et al., 2005; Camp et al., 1991). Lavas from the Red Sea ocean floor are

256 dominantly more tholeiitic than harrat lavas (Figure 4; Essien et al., 1989; Kelley et al., 257 2013).

258 Bivariate diagrams comparing major oxides and selected trace element and trace

259 element ratios to $\mathrm{MgO}$ contents are shown in Figures 5, 6 and 9. $\mathrm{SiO}_{2}, \mathrm{Al}_{2} \mathrm{O}_{3}, \mathrm{Na}_{2} \mathrm{O}, \mathrm{TiO}_{2}$

260 and $\mathrm{CaO}$ show broadly increasing trends with increasing $\mathrm{MgO}$, consistent with crystal

261 fractionation, although there is also considerable scatter, particularly for $\mathrm{Na}_{2} \mathrm{O}, \mathrm{TiO}_{2}$ and

$262 \mathrm{CaO} . \mathrm{FeO}^{*}$ contents are also scattered but remain broadly constant with decreasing $\mathrm{MgO}$.

263 Compatible trace elements (e.g., $\mathrm{Cr}$ and $\mathrm{Ni}$ ) follow simpler trends that reflect decreasing

264 concentrations to lower $\mathrm{MgO}$, consistent with significant olivine fractionation.

265 Incompatible elements typically increase with decreasing $\mathrm{MgO}$, although as with major

266 elements these trends show more scatter (Figure 6). Ratios of similarly incompatible trace

267 elements, e.g., $\mathrm{Nb} / \mathrm{Zr}, \mathrm{Ba} / \mathrm{Nb},[\mathrm{La} / \mathrm{Sm}]_{\mathrm{N}}$, do not change systematically with $\mathrm{MgO}$ (Figures

268 6, 9). Hutaymah lavas show consistent light REE enrichment and heavy REE depletion 
269 (Figure 7). $[\mathrm{La} / \mathrm{Yb}]_{\mathrm{N}}$ and $[\mathrm{Dy} / \mathrm{Yb}]_{\mathrm{N}}$ ratios range from 6-29 and 1.6-1.9, respectively. 270

271

272

273

\section{Discussion}

\section{Timing of Hutaymah Magmatism}

274

The age of Harrat Hutaymah volcanism has been estimated previously to be 0.1 to

2752.7 Ma, employing the conventional K/Ar dating method (Pallister, 1984; Thornber,

276 1992). While the new ${ }^{40} \mathrm{Ar}^{-39} \mathrm{Ar}$ ages reported here fall within this range, our data also

277 suggest that Hutaymah volcanism occurred over a much shorter period, from 260-850 Ka.

278 In one particular example, sample HH-1 was collected at the same location (Al Hutaymah

279 tuff ring, Figure 2) from which Pallister (1984) reported an age of 1.84 \pm 0.05 Ma. But

280 our ${ }^{40} \mathrm{Ar}-{ }^{39} \mathrm{Ar}$ laser step heating experiment produced a significantly younger age of 259

$281 \pm 120 \mathrm{Ka}$ (Table 3 ). An additional consideration comes from field measurement of

282 magnetic polarity preserved in the lava flows - all observed polarities were normal,

283 implying that most of Hutaymah volcanic activity is Brunhes age ( $\leqq 780 \mathrm{Ka})$. We explain

284 the disparity between older $\mathrm{K} / \mathrm{Ar}$ ages reported previously and $0 \mathrm{ur}^{40} \mathrm{Ar}^{39} \mathrm{Ar}$ ages by

285 undetected fragments of the abundant xenolithic material commonly found in Hutaymah

286 lavas, which carries un-degassed ("excess") ${ }^{40} \mathrm{Ar}$ and results in erroneously old total

287 fusion ages.

288

Field observation and petrographic analysis of Hutaymah rocks reveal that many

289 contain xenolithic fragments, from dispersed xenocrysts (sieved plagioclase and quartz)

290 to fist-size poly-crystalline nodules (Thornber, 1990, 1992). We believe these fragments

291 of largely crustal material (granitic and dioritic plutons, aged 670-550 Ma, Stoeser and

292 Elliott, 1980) to be the cause of disturbed (non-plateau) ${ }^{40} \mathrm{Ar}-{ }^{39} \mathrm{Ar}$ age spectra seen for 
293 several samples (Table 3 and Figure 3), and likely responsible for the older previously

294 reported $\mathrm{K} / \mathrm{Ar}$ ages. Other samples produced clear plateau ages comprising $60 \%$ or more

295 of the total gas released, with concordant isochrons and ${ }^{40} \mathrm{Ar} /{ }^{36} \mathrm{Ar}$ intercepts within

296 analytical uncertainty of the atmospheric value (295.5). Hence the new ages reported here

297 are more reliable than previous K/Ar ages because the significance of xenolithic material

298 can be evaluated from the non-concordance of step ages, and non-atmospheric initial Ar 299 compositions.

300 The newly dated lava flows were vented from eruptive centers spanning the full

301 geographic extent of Harrat Hutyamah. The ages do not suggest any consistency in

302 overall time-space variation of volcanism throughout the area. The youngest lava flow

303 measured, in the wall of the Al Hutaymah tuff ring (HH-1, $260 \mathrm{Ka}$;), is post-dated by that

304 eruptive event. Somewhat younger lava flows in the area of Al Qufayl (Figure 2) are

305 reported by Thornber (1992) as "less than $100 \mathrm{ka",} \mathrm{based} \mathrm{on} \mathrm{an} \mathrm{unpublished} \mathrm{K/Ar} \mathrm{age.}$

306 Some of the oldest lava flows (e.g. 176710, $848 \mathrm{ka} ; 176734,868 \mathrm{Ka}$ ) were erupted from

307 isolated monogenetic vents and others (HH-11, $844 \mathrm{Ka}$;) post-date earlier tuff-ring

308 explosions (Thornber, 1992). Hence, while our sampling has not fully bracketed the

309 volcanic history, the coverage and consistency of age determinations most likely

310 indicates that Hutaymah volcanism was confined to late Quaternary (Brunhes magnetic

311 chron) time.

312

$313 \quad$ Magmatic Evolution

314 Harrat Hutaymah lavas show important variations in their chemical composition

315 (Figures 4-7). There are a number of possible sources for this variability and we 
316 investigate them below. Forward modeling of the liquid line of descent for a

317 representative Hutaymah primary magma (Table 4) suggests that much of the variability

318 evident in major element abundances relates to polybaric crystal fractionation over a

319 range of upper mantle and crustal pressures. Note that this approach does not imply that

320 all erupted magmas derive from fractionation of the same primary magma batch, but does

321 suggest that the compositions of erupted magmas can be broadly explained by a similar

322 set of primary magma compositions and fractionation processes. We also recognize that

323 complications from magma mixing and contamination by antecrystic phases can also

324 obscure liquid lines of descent (e.g. Kent et al., 2002; Thomson and Maclennan, 2013).

325 Nevertheless the observed variations in composition are broadly consistent with our

326 petrographic observations and observed chemical variations, suggesting that forward

327 modeling of crystal fractionation is a reasonable means to interpret chemical variations in

328 these lavas. The earliest stages of crystal fractionation are largely dominated by olivine,

329 as evident from deceasing $\mathrm{Ni}$ and $\mathrm{Cr}$ with $\mathrm{MgO}$, and this is also consistent with the

330 widespread presence of olivine as a phenocryst phase. Clinopyroxene is also evident as a

331 groundmass and minor euhedral phenocryt phase, and low $\mathrm{CaO}$ contents (Figure 5) and

$332 \mathrm{CaO} / \mathrm{Al}_{2} \mathrm{O}_{3}$ in some lava compositions provide evidence for clinopyroxene fractionation

333 at lower $\mathrm{MgO}$ contents. The onset of clinopyroxene crystallization is a function of

334 pressure, and occurs earlier in the liquid line of descent at higher pressures. Thus

335 indications of clinopyroxene removal provide a means to constrain the pressure(s) of

336 crystal fractionation. Hutaymah lavas exhibit a range of $\mathrm{CaO}$ contents at a given with

$337 \mathrm{MgO}$, with shifts to lower $\mathrm{CaO}$ occurring in lavas with $\mathrm{MgO}$ contents as high as $\sim 12$

338 wt.\% (Figure 5). As a result Hutaymah lava compositions appear consistent with some 
339 clinopyroxene fractionation occurring at pressures in excess of $1 \mathrm{GPa}$ and continuing to

340 pressures as low as $100 \mathrm{MPa}$. The observed variations in $\mathrm{CaO}$ (and $\mathrm{Na}_{2} \mathrm{O}, \mathrm{Al}_{2} \mathrm{O}_{3}$ and

$341 \mathrm{FeO}$ ) in Hutaymah lavas can thus be broadly explained by olivine and clinopyroxene

342 fractionation occurring over a range of pressures equivalent to the uppermost mantle

343 through to intra-crustal depths. In some cases magma must have been transported

344 relatively rapidly from deep within the crust or mantle to the surface. Deep magma

345 residence and fractionation followed by rapid ascent is also necessary for survival of the

346 lithospheric and deep crustal xenoliths that are abundant in many Hutaymah lavas (e.g.

347 Thornber, 1992).

348 In spite of forming from magmas that have traversed thick continental lithosphere,

349 and transporting a range of crustal and upper mantle xenoliths (Thornber, 1992; Coleman,

350 1993), Harrat Hutaymah lavas show little evidence for compositional modification via

351 crustal assimilation. This is evident in isotopic compositions, which fall in a narrow,

352 unradiogenic range $\left({ }^{87} \mathrm{Sr} /{ }^{86} \mathrm{Sr}: 0.70339-0.70349 ;{ }^{143} \mathrm{Nd} /{ }^{144} \mathrm{Nd}: 0.51286\right.$, or $\varepsilon_{\mathrm{Nd}} \sim 4.2$;

353 Altherr et al., 1990; Thornber, 1992), compared with shield crustal rocks ( $\varepsilon_{\mathrm{Nd}} \sim 1$;

$\left.354{ }^{87} \mathrm{Sr} /{ }^{86} \mathrm{Sr} \sim 0.706\right)$. In part this is due to the intrinsically high incompatible element

355 abundances in many of these magmas, although the effects of crustal contamination

356 remain surprisingly minor. For example trace element ratios such as $\mathrm{Ba} / \mathrm{Nb}$ and $\mathrm{K} / \mathrm{Nb}$ that

357 are sensitive to crustal assimilation (and would remain unfractionated by fractional

358 crystallization) remain low and do not increase with decreasing $\mathrm{MgO}$ contents (e.g.

359 Figures 6, 9). Potassium contents and $\mathrm{K} / \mathrm{Nb}$ in Hutaymah lavas range between 500-1500

$360 \mu \mathrm{g} / \mathrm{g}$ and $80-200$ relative to crustal values of 28,000 and 500-2000 (average upper crust

361 compositions; e.g. Baker et al., 1996; Kent et al., 2002). Calculated trends for 
362 assimilation-fractional crystallization trends (AFC) for $\mathrm{K}$ contents and $\mathrm{K} / \mathrm{Nb}$ ratios

363 (Figure 9) show that significant assimilation during progressive crystal fractionation

364 would rapidly increase $\mathrm{K}$ and $\mathrm{K} / \mathrm{Nb}$, and thus the compositions of Hutaymah lavas are

365 consistent with assimilation occurring only at ratios of mass of material assimilated to

366 that crystallized $(r)<<0.1$. Incompatible element abundances are also modified during

367 crystal fractionation, however the variations evident in incompatible element contents are

368 larger than can be explained by fractional crystallization or crustal assimilation alone, and

369 likely also reflect variation in the degree of partial melting and/or mantle source

370 composition.

371 Ultramafic nodules brought to the surface in lavas and tephras provide a detailed

372 sampling of the composition, mineralogy and thermal history of the subcontinental

373 lithosphere beneath Harrat Hutaymah (Thornber, 1992). Thornber (1994) divided these

374 xenoliths into Cr-diopside and Al-augite lithologies, which were further divided into 26

375 rock types based on mineralogy and texture. The Al-augite lithologies are believed to

376 have been entrained from $\pm 10 \mathrm{~km}$ of the crust-mantle boundary (about $40 \mathrm{~km}$ depth in

377 this region, Healey et al., 1982), while the Cr-diopside nodules come from depths up to

$37870 \mathrm{~km}$, based on two-pyroxene thermometric estimates (Wells, 1977). Both groups

379 include anhydrous and hydrous examples. The Nd-isotopic compositions of the

380 metamorphic mantle xenoliths define a pseudo-isochron of $\sim 700 \mathrm{Ma}$, consistent with the

381 Proterozoic age of crustal shield rocks and xenoliths from other nearby harrats (Stoeser

382 and Camp, 1985; Krienitz and Haase, 2011). The deeper-sourced, high temperature

383 pyroxenites and partial melt-bearing peridotites have $\mathrm{Sr}$ - and $\mathrm{Nd}$-isotopic compositions

384 that match the narrow range of Hutaymah lava compositions, which led Thornber (1992) 
385 to propose that they formed contemporaneously with the Quaternary volcanic activity

386 (i.e., synrift), as residual mantle from partial melting or through melt-wall rock

387 interaction. The latter admits the possibility that melts formed somewhat deeper

388 (asthenosphere) and reacted with the deep lithosphere in transit to the surface.

389

390 Constraints on Mantle Source Composition and Melting

391 Variations in REEs and other trace elements can be used to constrain the mantle

392 source composition and melting conditions involved in magma generation. Overall, as

393 noted above, the considerable range of incompatible element abundances at a given $\mathrm{MgO}$

394 content (Figure 6) suggest that crystal fractionation and assimilation are unlikely to be the

395 sole source of incompatible element variations, and differences in the degree of melting

396 and/or mantle source composition have also exerted important controls on trace element

397 abundance.

$398 \quad$ Mantle melting in intraplate settings is strongly effected by both the solidus

399 pressure, melt productivity and pressure at which melting ceases, the latter controlled by

400 the thickness of the overlying cold lithospheric "lid" (e.g. McKenzie and O'Nions, 1991;

401 Fram and Lesher, 1992). Examination of REE patterns (Figure 7) shows that all

402 Hutaymah magmas are strongly enriched in LREE ([La/Sm $\left.]_{\mathrm{N}} \sim 2-4.5\right)$, and have ratios of

403 MREE to HREE (e.g. [Sm/Yb $]_{\mathrm{N}} \sim 2.5-4.5$ ) consistent with some melting occurring at

404 sufficient depth to be in equilibrium with residual garnet. These REE features, as well as

405 the enriched $\mathrm{Sr}$ and $\mathrm{Nd}$ isotope compositions of Hutaymah and other harrat magmas

406 (Altherr et al., 1990) are also consistent with melting of an enriched mantle composition.

407 Simple batch melting calculations support this and suggest that the broad REE 
408 characteristics of Hutaymah lavas could be produced by melting of garnet lherzolite with

409 a primitive mantle composition source.

410 To constrain melting conditions further we have used the approach of Fram and

411 Lesher (1992) and Brown and Lesher (2014) to calculate forward models of REE

412 contents produced under different melting conditions. Duncan and Al-Amri (2013)

413 applied this approach to magmas from Harrat Lunayyir, further to the west, and we now

414 extend this treatment to Hutaymah. Calculations herein used the MATLAB script

415 "REEBOX" (Brown and Lesher, 2014). We use a primitive mantle source composition in

416 order to reproduce the highest $[\mathrm{La} / \mathrm{Sm}]_{\mathrm{N}}$ values that we observe at Hutaymah, as it was

417 not possible to produce these values using a depleted MORB source mantle. The

418 REEBOX approach is based on forward modeling of non-modal incremental batch

419 melting in an upwelling mantle melting column (Fram and Lesher, 1992). The

420 compositions of pooled incremental polybaric non-modal batch melts produced by

421 melting along the extent of an entire upwelling melting column can be compared to

422 observed compositions to constrain the pressure at which melting started and ceased, and

423 to estimate the degree of melting.

424 We use partition coefficients for REE from McKenzie and O’Nions (1991). Melt

425 productivity is set at $1.0 \%$ per $0.1 \mathrm{GPa}$. Results appear in Figure 8, where the

426 compositions of aggregated melts are shown. We also show the pressures of the

427 beginning and ending of melting and equivalent melt fraction (see figure caption). These

428 results suggest that melting beneath Hutaymah started at pressures of $\sim 2.5-2.6 \mathrm{GPa}$ and

429 continued up to pressures of 1.8-2.5 GPa, consistent with a lithospheric thickness of 60-

43080 km. Earlier authors (e.g. Camp and Roobol, 1992; Duncan and Al-Amri, 2013) have 
431 argued that melting beneath harrats that lie away from the center of the MMN line

432 occurred under thicker lithosphere, and our results are consistent with this. Melting

433 underneath Harrat Lunayyir, another volcanic field peripheral to the MMN line (Figure 1)

434 started at 2.2-2.4 GPa and continued until 1.4-2.1 GPa, equivalent to a lithospheric

435 thickness of $\sim 45-70 \mathrm{~km}$. Melting beneath Harrat Rahat, which is central to the MMN line

436 started at 2.4-2.8 GPa, but continued until 1.2-1.6 GPa, equivalent to a lithospheric

437 thickness of only $40-50 \mathrm{~km}$. The degree of melting also varies between these three harrats,

438 with the Hutaymah having values that range from $\sim 1-7 \%$, Lunayyir $\sim 2-10 \%$ and Rahat

$439 \quad 11-15 \%$.

440 Lava flow compositions from the Red Sea have distinctly lower $[\mathrm{La} / \mathrm{Sm}]_{\mathrm{N}}$ and

$441[\mathrm{Dy} / \mathrm{Yb}]_{\mathrm{N}}$ ratios and less radiogenic isotopic compositions relative to harrat lavas,

442 suggesting that overall they derive from greater degrees of melting at shallower depths,

443 and form from a more depleted mantle source (e.g. Altherr et al., 1990; Camp and Roobol,

444 1992). The forward model calculations we show in Figure 8 cannot be directly applied to

445 Red Sea lavas as we use a Primitive Mantle source that is likely to be more enriched that

446 the depleted mantle MORB source for Red Sea lavas (Altherr et al., 1990). Preliminary

447 modeling using a MORB source depleted mantle suggests lithospheric thicknesses of $<<$

$44810 \mathrm{~km}$ for Red Sea lavas, consistent with typical models for MORB formation from

449 shallow melting with little or no lithosphere present. This is also consistent with the

450 findings of Duncan and Al-Amri (2013).

451 It is also interesting to note that MELTS models do not adequately describe the

452 observed changes in $\mathrm{TiO}_{2}$ contents as a function of clinopyroxene fractionation. This is

453 also consistent with the observation that $\mathrm{TiO}_{2}$ contents do not correlate strongly with 
454 other moderately incompatible major elements or with $\mathrm{CaO}$. Instead the highest

455 correlation coefficients are observed between $\mathrm{TiO}_{2}$ and the middle REE, suggesting that

456 initial $\mathrm{TiO}_{2}$ contents are variable and strongly influenced by the same variations in mantle

457 source and melting that control REEs.

458

459 Evidence for Mantle Plume Influence

460 Several factors indicate that the harrat magmatic province is not simply the result

461 of passive mantle upwelling and melting in response to regional extension associated

462 with Africa-Arabia plate separation, now focused at the Red Sea spreading ridge. First,

463 the uplift, erosion and extent of volcanic activity are not symmetric across the extending

464 region. Secondly, the subcontinental lithosphere beneath the Arabian shield has been

465 variably thinned. While lithosphere thins rapidly near the eastern margin of the Red Sea

466 (Healey et al., 1982), there is anomalously thin lithosphere (inferred from seismic and 467 geochemical data) beneath the N-S Makkah-Madinah-Nafud (MMN) line also associated

468 with the largest volcanic fields (see above; also Mooney et al., 1985; Gettings et al.,

469 1986; Julia et al., 2003). These observations point to active mantle flow that provides

470 thermal buoyancy for lithospheric uplift, and possible thermal erosion of the

471 asthenosphere-lithosphere boundary beneath focused regions of the Arabian shield.

472 Active upwelling is proposed by Camp and Roobol (1992) and Krienitz et al.

473 (2009), who suggest that radial flow of upper mantle material from the Afar mantle

474 plume may have influenced the tectonics and distribution of volcanism in the region.

475 Additional information about upper mantle flow comes from seismic anisotropy studies

476 (Hansen et al., 2006, 2007). Chang and van der Lee (2011) report jointly inverted 
477 teleseismic S- and SKS-arrival times, regional S- and Rayleigh waveform fits,

478 fundamental-mode Rayleigh wave-group velocities, and independent Moho constraints

479 that provide complementary resolution for the three-dimensional (3-D) S-velocity

480 structure beneath the region. Specifically, Chang and van der Lee (2011) find distinct

481 low-velocity anomalies in the uppermost mantle, along with shear-wave splitting results

482 that indicate horizontal mantle flow radially from Afar. This radial flow seems to be

483 organized in channels, potentially following thin lithosphere. One such channel follows

484 the Gulf of Aden, supporting the notion of eastward-directed mantle flow from Afar.

485 Another channel extends northward beneath the southern Red Sea, but rather than

486 following the NW-trending Red Sea spreading axis, it continues northwards beneath

487 western Saudi Arabia, aligned with the MMN line.

488 Trace element and isotopic data are consistent with the origin of harrat magmas

489 from partial melting of enriched (plume-influenced) mantle, rather than depleted mantle,

490 which is the source for Red Sea basalts (e.g. Altherr et al., 1990; Fitton et al., 1997).

491 Recent study of the He-isotopic composition of Hutaymah xenoliths and lavas (Konrad et

492 al., pers. comm., October, 2015) finds a remarkable uniformity in xenolith ${ }^{3} \mathrm{He} /{ }^{4} \mathrm{He}$ ratios,

493 with a weighted mean of $7.55 \pm 0.03 \mathrm{R}_{\mathrm{A}}(2 \sigma, \mathrm{n}=18)$, across eight different xenolith types.

494 A somewhat lower value, $6.8 \pm 0.1 \mathrm{R}_{\mathrm{A}}$ was measured in the least altered (high

495 temperature, anhydrous) spinel lherzolite. Olivine from non-xenolith bearing lavas falls

496 within the range of xenolith compositions. From these results and complementary $\mathrm{CO}_{2}$

497 and trace element data (Konrad et al., pers. comm., October, 2015) it appears that the

498 subcontinental lithosphere beneath the harrats region has been altered by fluid-rich partial

499 melts from the asthenosphere, which slightly raised the ${ }^{3} \mathrm{He} /{ }^{4} \mathrm{He}$ composition from $\sim 6.8$ 
500 to $7.5 \mathrm{R}_{\mathrm{A}}$. However, if the asthenosphere was influenced by mantle flow from the Afar 501 region, the He signature was largely degassed before melting beneath Hutaymah. In

502 contrast, Murcia et al. (2013) find more elevated ${ }^{3} \mathrm{He} /{ }^{4} \mathrm{He}$ values (9.3 to $11.7 \mathrm{R}_{\mathrm{A}}$ ) in

503 historic lava flows at Harrat Rahat. This much larger volcanic field sits along the MMN

504 line, directly above the geophysically-imaged thinned lithosphere, and may reflect more 505 vigorous asthenospheric flow.

506

\section{$507 \quad$ Harrat Hutaymah Petrogenesis and Regional Implications}

508 The data obtained over the course of this research challenges previous models for

509 the petrogenesis of Harrat Hutaymah and the harrat region as a whole. New ${ }^{40} \mathrm{Ar}-{ }^{39} \mathrm{Ar}$

510 ages ranging from 260 to 850 Ka suggest that Harrat Hutaymah formed more rapidly and

511 recently than previously thought. Also, samples analyzed in this research, as well as those

512 studied from Harrat Lunayyir and Harrat Rahat, are consistent with formation from a

513 plume-influenced source (Fitton et al., 1997). It has been proposed that the petrogenesis

514 of Harrat Hutaymah and the entire harrat region can be explained by simple 515 decompression melting related to the rifting of the Red Sea (Hempton, 1987; Coleman 516 and McGuire, 1988; Thornber, 1992). However, the variability of depth and degree of

517 melting, differences in timing among harrats, as well as the significant compositional 518 variation observed throughout the province, suggest that the situation is more complex.

519 The model we propose explains the petrogenesis of Harrat Hutaymah and the rest 520 of the harrat region with regional extension resulting in decompression melting coupled 521 with northward asthenospheric flow from the Afar plume (Figure 10). It is likely that the 522 older, Red Sea parallel, volcanic fields ( $>12 \mathrm{Ma})$ are the result of simple decompression 
523 melting due to rifting of the Red Sea, as suggested by their orientation and tholeiitic

524 compositions. However, the younger $(<12 \mathrm{Ma}) \mathrm{N}-\mathrm{S}$ oriented volcanic fields (Hutaymah,

525 Lunayyir, Rahat etc.) that together make up the Makkah-Madinah-Nafud (MMN) line are

526 best explained by regional lithospheric thinning, possibly in concert with thermal erosion,

527 coupled with northward flow of asthenospheric material likely derived from the Afar

528 plume. Investigation of some of the larger, longer-lived volcanic fields (e.g., Rahat,

529 Khaybar) should reveal the timing of changes in the lithosphere-asthenosphere boundary.

530

\section{Acknowledgements}

532

533

Kyle Krawl provided assistance with instruction in using the geochemical

534 modeling software. ICP-MS and additional XRF analyses were provided by the

535 Washington State University GeoAnalytical Laboratory. Dr. Dan Miggins assisted with

$536{ }^{40} \mathrm{Ar}-{ }^{39} \mathrm{Ar}$ incremental heating analyses. We thank Dr. Saeed Alshaltoni for assistance

537 with sample collection and thin section preparation. R.A.D. acknowledges support from

538 the Distinguished Scientist Fellowship Program at King Saud University. Chip Lesher

539 provided access to the REEBOX package. Parts of this research were supported by the

540 King Abdulaziz City for Science and Technology (KACST) and the National Science

541 Foundation (award 1524675).

542 


\section{References}

544 Altherr, R., Henjes-Kunst, F. and Baumann, A., 1990. Asthenosphere versus lithosphere as possible sources for basaltic magmas erupted during formation of the Red Sea: constraints from $\mathrm{Sr}, \mathrm{Pb}$ and $\mathrm{Nd}$ isotopes. Earth Planet. Sci. Lett., 96: 269-286.

Baedecker, P.A. and McKown, D.M., 1987. Instrumental neutron activation analysis of geochemical samples. U.S. Geological Survey Bulletin 1770, 16p.

Baker, J.A., Thirwall, M.F., Menzies, M., 1996. Sr-Nd-Pb iso- topic and trace element evidence for crustal contamination of plume-derived flood basalts: Oligocene flood volcanism in western Yemen, Geochim. Cosmochim. Acta 60: 2559-2581.

Bohannon, R.G., C.W. Naeser, D.L. Schmidt, R.A. Zimmerman, (1989). The timing of uplift, volcanism, and rifting peripheral to the Red Sea — a case for passive rifting? $J$. Geophys. Res., 94:1683-1701.

Bramkamp, R.A., Ramirez, L.F., Brown, G.F., and Pocock, A.E., 1963. Geology of the Wadi Ar Rimah Quadrangle, Kingdom of Saudi Arabia. U.S. Geological Survey Miscellaneous Investigations Map I-206A, scale 1:500,000.

Brown, E.L. and Lesher, C.E., 2014. North Atlantic magmatism controlled by temperature, mantle composition and buoyancy. Nature Geoscience, $10.1038 /$ ngeo2264.

Camp, V.E., and M.J. Roobol, 1992. Upwelling asthenosphere beneath western Arabia and its regional implications. J. Geophys. Res., 90, 15,255-15,271.

Camp, V.E., Roobol, M.J. and Hooper, P.R., 1991. The Arabian continental alkali basalt province: Part II. Evolution of Harrats Khaybar, Ithnayn, and Kura, Kingdom of Saudi Arabia. Geol. Soc. Amer. Bull., 103: 363-391.

Chang, S., and S. van der Lee, 2011. Mantle plumes and associated flow beneath Arabia and East Africa. Earth Planet. Sci. Lett., 302, 448-454.

Coleman, R.G., 1993. Geologic Evolution of the Red Sea. Oxford Monographs on Geology and Geophysics, Oxford University Press, pp. 186.

Coleman, R.G., and A.V. McGuire, 1988. Magma systems related to the Red Sea opening. Tectonophysics, 150: 77-100.

Dalrymple, G.B., and M.A. Lanphere, 1969, Potassium-Argon Dating: W.H. Freeman and Company, San Francisco, 258 p.

Dixon, J. E., D. A. Clague, and E. M. Stolper. 1991. Degassing history of water, sulfur, and carbon in submarine lavas from Kilauea Volcano, Hawaii. J. Geol., 371-394. 
588

589

590

591

592

593

594

595

596

597

598

599

600

601

602

603

604

605

606

607

608

609

610

611

612

613

614

615

616

617

618

619

620

621

622

623

624

625

626

627

628

629

630

631

632

633

Duncan, R. A., A.M. Al-Amri, 2013. Timing and composition of volcanic activity at Harrat Lunayyir, western Saudi Arabia. J. Volcanol. Geotherm. Res., 260, 103-116.

Essien, J.-P., Juteau, T., Joron, J.-J., Dupre, B., Humler, E. and Al'Mukhamedov, A., 1989. Petrology and geochemistry of basalts from the Red Sea axial rift at $18^{\circ} \mathrm{N} . J$. Petrol., 30: 791-839.

Fitton, J.G., A.D. Saunders, M.J. Norry, B.S. Hardarson, and R.N. Taylor, (1997). Thermal and chemical structure of the Iceland plume. Earth Planet. Sci. Lett., 153, 197-208.

Fram, M.S. and Lesher, C.E., 1993. Geochemical constraints on mantle melting during creation of the North Atlantic basin. Nature, 363: 712-715.

Gettings, M.E., Blank, H.R., Mooney, W.D., and Healey, J.H., 1986. Crustal structure of southwestern Saudi Arabia. J. Geophys. Res., 91: 6491-6512.

Ghiorso, M. S., and R.O. Sack, 1995. Chemical mass transfer in magmatic processes IV. A revised and internally consistent thermodynamic model for the interpolation and extrapolation of liquid-solid equilibria in magmatic systems at elevated temperatures and pressures. Contrib. Mineral. Petrol., 119(2-3), 197-212.

Gurenko, A. A., and M. Chaussidon, 1995. Enriched and depleted primitive melts included in olivine from Icelandic tholeiites: origin by continuous melting of a single mantle column. Geochim. Cosmochim. Acta, 59, 2905-2917.

Hansen, S.E., Schwarz, S. Al-Amri, A.M. and Rodgers, A., 2006. Combined plate motion and density driven flow in asthenosphere beneath Saudi Arabia: evidence from shearwave splitting and seismic anisotropy. Geology, 34: 869-872.

Hansen, S.E., Rodgers, A., Schwarz, S. and Al-Amri, A.M., 2007. Imaging ruptured lithosphere beneath the Red Sea and Arabian peninsula. Earth Planet. Sci. Lett., 259: 256-265.

Healey, J.H., Mooney, W.D., Blank, H.R., gettings, M.E., Kohler, W.M., Lamson, R.J. and Leone, L.E., 1982. Saudi Arabian Seismic Deep-Refraction Profile: Final Project Report. Ministry of Petroleum and Mineral Resources, Deputy Ministry for Mineral Resources, Kingdom of Saudi Arabia (Open File Report USGS-OF-02-37, 141 pp.).

Hempton, M.R., 1987. Constraints on Arabian plate motion and extensional history of the Red Sea. Tectonics 6: 687-705.

Johnson, D.M., Hooper, P.R., Conrey, R.M., 1999. XRF analysis of rocks and minerals for major and trace elements on a single low dilution Li-tetraborate fused bead. Advances in X-ray Analysis 41: 843-867. 
634

635

636

637

638

639

640

641

642

643

644

645

646

647

648

649

650

651

652

653

654

655

656

657

658

659

660

661

662

663

664

665

666

667

668

669

670

671

672

673

674

675

676

677

Julia, J., Ammon, C. and Hermann, R., 2003. Lithosphere structure of the Arabian Shield from joint inversion of receiver functions and surface-wave group velocities. Tectonophysics, 371: 1-21.

Kelley, K.A., R.H. Kingsley, and J.G. Schilling, 2013. Composition of Plume-Influenced Mid-Ocean Ridge Lavas and Glasses from the Mid-Atlantic Ridge, East Pacific Rise, Galapagos Spreading Center, and Gulf of Aden. Geochemistry, Geophysics, Geosystems, 14, 223-242.

Kent, A.J.R., Baker, J.A. \& Wiedenbeck, M., 2002. A melt inclusion-based study of crustal contamination and melt column aggregation in continental flood basalts from Yemen. Earth Planet. Sci. Lett. 202: 577-594.

Knaack, C., Cornelius, S.B., and Hooper, P.R., 1994. Trace element analyses of rocks and minerals by ICP-MS. Technical Notes, GeoAnalytical Lab, Washington State University.

Koppers, A.A.P., 2002. ArArCALC - software for Ar-40/Ar-39 age calculations. Computers \& Geosciences, 28(5), 605-619.

Krienitz, M.S., Haase, K.M., Mezger, K., van den Bogaard, P., Thiemann, V. and ShaikhMashail, M.A., 2009. Tectonic events, continental intraplate volcanism, and mantle plume activity in northen Arabia: constraints from geochemistry and Ar-Ar dating of Syrian lavas. Geochem. Geophys. Geosys., 10. Doi/10.1029/2008GC002254.

Krienitz, M.-S., and K. M. Haase, 2011. The evolution of the Arabian lower crust and lithospheric mantle - geochemical constraints from southern Syrian mafic and ultramafic xenoliths. Chemical Geology, 280: 271-283.

Kuiper, K. F., Deino, A., Hilgen, F. J., Krijgsman, W., Renne, P. R., Wijbrans, J. R., 2008. Synchronizing rock clocks of earth history. Science 320, 500- 504.

Johnson, M. C., A. T. Anderson, and M. J. Rutherford. 1994. Pre-eruptive volatile contents of magmas. Rev. Mineral. Geochem., 30: 281-330.

McDonough, W. F. and S. S. Sun, 1989. Chemical and Isotopic Systematics of Ocean Basalts: Implications for Mantle Composition and Processes. Geol. Soc., London, Spec. Publ., 42: 313-345.

McKenzie, D. and O'Nions, R.K., 1991. Partial melt distributions from inversion of rare earth element concentrations. J. Petrol., 32: 1021-1091.

Mooney, W.D., Gettings, M.E., Blank, H.R. and Healey, J.W., 1985. Saudi Arabian seismic deep refraction profile: travel-time interpretation of crust and upper mantle 
678

679

680

681

682

683

684

685

686

687

688

689

690

691

692

693

694

695

696

697

698

699

700

701

702

703

704

705

706

707

708

709

710

711

712

713

714

715

716

717

718

719

720

structure. Tectonophysics, 111: 173-246.

Moufti, M.R.H, and M.H. Hashad, 2005.Volcanic Hazards Assessment of Saudi Arabian Harrats: Geochemical and isotopic Studies of Selected Areas of Active MakkahMadinah-Nafud (MMN) Volcanic Rocks. Final Report (LGP-5-27). King Abdulaziz City for Science and Technology, Riyadh, Saudi Arabia.

Moufti, M.R., Moghazi, A.M. and Ali, K.A., 2012. ${ }^{40} \mathrm{Ar} /{ }^{39} \mathrm{Ar}$ geochronology of the Neogene-Quaternary Harrat Al-Madinah intercontinental volcanic field, Saudi Arabia: Implication for duration and migration of volcanic activity. J. Asian Earth Sci.

Murcia, H., J.M. Lindsay, S. Niedermann, S.J. Cronin, I.E.M. Smith, N.N. El-Masry, M.R.H. Moufti, K. Nemeth, 2013. The potential use of cosmogenic nuclides for dating in Harrat Rahat. Vorisa Scientific Meeting, 24-28.

Pallister, J.S., 1984. Reconnaissance Geology of the Harrat Hutaymah Quadrangle, Sheet 26/42 A, Kingdom of Saudi Arabia: Ministry of Petroleum and Mineral Resources, Deputy Ministry for Mineral Resources, Jeddah, Kingdom of Saudi Arabia, OpenFile Report USGS-OF_04-46, 77 p.

Pallister, J.S., 1987. Magmatic history of Red Sea rifting: perspective from the central Saudi Arabian coastal plain. Geol. Soc. Amer. Bull., 98: 400-417.

Putirka, K. (2005) Mantle potential temperatures at Hawaii, Iceland, and the mid-ocean ridge system, as inferred from olivine phenocrysts: Evidence for thermally-driven mantle plumes. Geochemistry, Geophysics, Geosystems, doi:10.1029/005GC000915

Quick, J.E. and Hellaby, A.B., 1988. Xap, a program for deconvolution and analysis of complex x-ray spectra. Technical Record USGS-TR-08-3, Ministry of Petroleum and Mineral Resources Directorate General of Mineral Resources. Jeddah, Kingdom of Saudi Arabia. 1408 AH.

Roeder, P.L. and Emslie, R.F., 1970. Olivine-liquid equilibrium. Contrib. Mineral. Petrol., 29: 275-289.

Shaw, J.E., J.A. Baker, M.A. Menzies, M.F. Thirlwall, K.M. Ibrahim, 2003. Petrogenesis of the largest intraplate volcanic field on the Arabian Plate (Jordan): a mixed lithosphere-asthenosphere source activated by lithospheric extension. J. Petrology, 44, 1657-1679.

Stoeser, D.B. and Camp, V.E., 1985. Pan African microplate accretion of the Arabian shield. Geol. Soc. Amer. Bull., 96: 817-826.

Thomson, A., and Maclennan, J., 2013. The Distribution of Olivine Compositions in Icelandic Basalts and Picrites. J. Petrology, 54: 745-768. 
721 Thornber, C.R., 1992. The Petrology, Geochemistry, and Origin of Ultramafic Inclusions and Mafic Alkaline Volcanics from Harrat Hutaymah, Saudi Arabia (Doctoral Dissertation). University of Colorado.

Thornber, Carl R., 1990. Geologic map of Harrat Hutaymah, Saudi Arabia, with the petrologic classification and distribution of ultramafic inclusions (1:100,000 scale), USGS Miscellaneous Field Studies Map MF-2129.

Vlastelic, I., L. Dosso, H. Guillou, H. Bougault, L. Geli, J. Etoubleau, and J.L. Joron, 1998. Geochemistry of the Hollister Ridge: Relation with the Louisville Hotspot and the Pacific-Antarctic Ridge. Earth Planet. Sci. Lett., 160, 777-793.

Wells, P.R.A., 1977. Pyroxene thermometry in simple and complex systems. Contrib. Mineral. Petrol., 62: 129-139. 
736 Table 1. Whole rock major and trace element concentrations from selected Harrat

737 Hutaymah lavas. Data obtained using XRF and ICP-MS methods. Major element

738 concentrations expressed as weight percent oxides. Trace element concentrations are

739 expressed as ppm. Iron is reported as total iron (II) oxide ( $\left.\mathrm{FeO}^{*}\right)$.

740 Table 2. Rare earth element concentrations ( $\mathrm{ppm}$ ) normalized to $\mathrm{C} 1$ chondrite

741 (McDonough \& Sun, 1989).

742 Table 3. Ages ( $\pm 2 \square$ ) calculated using sanidine monitor FCT-3 (28.201 Ma, Kuiper et al.,

7432008 ) and the total decay constant $\lambda=5.530 \mathrm{E}-10 / \mathrm{yr}$. $\mathrm{N}$ is the number of heating steps

744 (defining plateau/total); MSWD is an F-statistic that compares the variance within step

745 ages with the variance about the plateau and isochron ages. J combines the neutron

746 fluence with the monitor age. Preferred ages are shown in bold; italics indicate sample

747 with suspected mantle-derived (excess) ${ }^{40} \mathrm{Ar}$.

748 Table 4. Primitive magma composition estimated from major and trace element variation

749 with $\mathrm{MgO}$ (Figures 5, 6), and $\mathrm{Mg}$ number $=0.72$. These elemental concentrations are

750 very similar to an average composition of most primitive lava compositions (Thornber,

751 1992).

752

753

754 Figure 1. Location map for volcanic fields ("harrats") in western Saudi Arabia (after

755 Chang and van der Lee, 2011). Individual harrats lie within $500 \mathrm{~km}$ of the Red Sea

756 margin, but eruptive centers/fissures are aligned predominantly N-S. The most

757 voluminous fields fall along the axis indicated by dotted red line (Ha'il Arch), also called

758 the Makkah-Medinah-Nafud (MMN) lineament. Harrat Hutaymah is a relatively small

759 field that lies east the MMN line.

760 Figure 2. Harrat Hutaymah, western Saudi Arabia. The various volcanic centers, mapped

761 in detail by Thornber (1990), are indicated as shaded areas on this satellite image. The

762 green stars mark the location of samples collected for age determinations and

763 geochemical analyses.

764 Figure 3. New ${ }^{40} \mathrm{Ar}^{-39} \mathrm{Ar}$ age spectra and isochron plots for Hutaymah lava flows. In age

765 spectra individual step ages are shown as open red boxes whose heights are $\pm 2 \mathrm{~s}$ plotted

766 against cumulative ${ }^{39} \mathrm{Ar}$ released (\%). Solid horizontal black bar indicates step ages used 
767 to calculate weighted mean plateau age. MSWD is the mean square of weighted 768 deviations. The isochrons plot ${ }^{40} \mathrm{Ar} /{ }^{36} \mathrm{Ar}$ vs ${ }^{39} \mathrm{Ar} /{ }^{36} \mathrm{Ar}$. The step compositions used in the

769 isochron plots are shown as green circles; not used are blue squares; total fusion

770 composition is the red circle. The red line indicates best fitting linear regression, whose

771 slope yields the isochron age.

772 Figure 4. Total Alkalis vs. Silica diagram comparing harrat province fields and Red Sea

773 lavas. Harrat Hutaymah lavas are red circles (Thornber, 1992) and blue squares (this

774 study). Fields representing data for Harrat Lunayyir (Duncan and Al-Amri, 2013), Harrat

775 Rahat (Moufti et al., 2005), and Red Sea lavas (Kelley et al. 2013;Vlastelic et al., 1998)

776 are also shown.

777 Figure 5. Variations in selected major element oxides vs. $\mathrm{MgO}$ in Harrat Hutaymah 778 samples from Thornber (1992) and this study. Also shown are calculated liquid lines of 779 descent for fractional crystallization of a representative primary liquid (see Table 5) 780 determined using MELTS (Ghiorso and Sack, 1995). Oxidation conditions were set at the

781 QFM buffer and calculations used an initial primary magma that contained $0.2 \mathrm{wt} . \% \mathrm{H}_{2} \mathrm{O}$.

782 Figure 6. $\mathrm{MgO}$ vs. (A) $\mathrm{Ba},(\mathrm{B}) \mathrm{Ba} / \mathrm{Nb}$, (C) $\mathrm{La},(\mathrm{D})[\mathrm{La} / \mathrm{Sm}]_{\mathrm{N}}$, (E) $\mathrm{Ni}$ and (F) $\mathrm{Cr}$ for

783 Harrat Hutaymah lavas from Thornber (1992) and this study.

784 Figure 7. Chrondrite normalized REE profiles for samples from Thornber (1992) and this 785 study. Normalized using compositions from McDonough and Sun (1995). Symbols as 786 for Figure 4.

787 Figure 8. $[\mathrm{La} / \mathrm{Sm}]_{\mathrm{N}}$ vs $[\mathrm{Dy} / \mathrm{Yb}]_{\mathrm{N}}$ for lavas from Harrat Hutaymah, Harrat Lunayyir, 788 Harrat Rahat and from the Red Sea. Data from Thornber (1992), this study, Duncan and 789 Al-Amri (2013), and Moufti et al. (2005). Red Sea lava data are from PETDB. Lines 790 show the result of REEBOX modeling (Fram and Lesher, 1992; Brown and Lesher, 791 2014). Solid red lines and red numerals show solidus pressure, black short dashed lines 792 and black numerals show the pressure of cessation of melting (equivalent thickness of the 793 lithospheric "lid"), and fine grey long dashed lines and grey numerals show the melt 794 fraction as percent. Pressures are in GPa. Modeling uses a primitive mantle starting 795 composition and partition coefficients from McKenzie and O’Nions (1991). Polybaric 796 melt productivity is $1 \%$ per $0.1 \mathrm{GPa}$. See text for more details. 
797 Figure 9. $\mathrm{K}$ and $\mathrm{K} / \mathrm{Nb}$ vs. $\mathrm{MgO}$ content. Data are shown for samples from this study and 798 from Thornber (1992) (see caption for Figure 6 for legend). Lines show calculated 799 assimilation-fractional crystallization (AFC) trends for ratios of mass assimilated to mass 800 crystalized $(r)$ of 0.1 and 0.5 . The assimilant is modeled after average upper continental 801 crust (see Baker et al., 1996 and Kent et al., 2002) and contains 28,220 $\mu \mathrm{g} / \mathrm{g} \mathrm{K,} 14 \mu \mathrm{g} / \mathrm{g}$ $802 \mathrm{Nb}$ and 2.5 wt.\% MgO.

803 Figure 10. Schematic cross-section of Harrat province petrogenesis. Regional thinning of 804 Arabian craton leads to decompression melting at the base of the continental lithosphere. 805 Additional thinning along the N-S trending MMN line may result from channelized 806 northward asthenospheric flow from the Afar region, bringing warmer and more plume -

807 like material. The coupled effect explains the variable depth and degree of melting and 808 the compositional variation observed across the region.

809

810

811

812 
Table 1. Major and trace element concentrations for basaltic whole rocks, Harrat Hutaymah

\begin{tabular}{|c|c|c|c|c|c|c|c|c|c|c|}
\hline Samples & HH-1 & HH-3 & HH-4 & HH-6 & HH-9 & HH-10 & HH-11 & HH-12 & 176701 & 176734 \\
\hline Latutude, N & $26^{\circ} 58.867$ & $26^{\circ} 50.617$ & $26^{\circ} 56.083$ & $26^{\circ} 57.617$ & $27^{\circ} 06.333$ & $27^{\circ} 04.767$ & $27^{\circ} 04.033$ & $27^{\circ} 02.750$ & $27^{\circ} 07.717$ & $27^{\circ} 04.050$ \\
\hline Longitude, E & $42^{\circ} 14.400$ & $42^{\circ} 15.017$ & $42^{\circ} 19.283$ & $42^{\circ} 19.483$ & $42^{\circ} 25.283$ & $42^{\circ} 21.650$ & $42^{\circ} 15.867$ & $42^{\circ} 25.500$ & $42^{\circ} 22.300$ & $42^{\circ} 20.950$ \\
\hline $\mathrm{SiO} 2$ & 45.97 & 45.43 & 47.05 & 45.10 & 47.75 & 44.97 & 48.94 & 44.68 & 46.08 & 46.08 \\
\hline TiO2 & 2.802 & 2.272 & 2.694 & 2.847 & 1.721 & 2.568 & 1.998 & 2.547 & 13.95 & 15.04 \\
\hline Al2O3 & 15.48 & 14.85 & 15.35 & 15.34 & 15.00 & 14.96 & 15.84 & 14.58 & 11.39 & 10.87 \\
\hline $\mathrm{FeO}^{*}$ & 12.23 & 11.36 & 10.63 & 11.07 & 11.05 & 11.19 & 11.69 & 11.94 & 10.04 & 10.08 \\
\hline MnO & 0.198 & 0.183 & 0.166 & 0.173 & 0.165 & 0.185 & 0.190 & 0.195 & 10.28 & 9.33 \\
\hline MgO & 7.09 & 10.51 & 7.32 & 7.65 & 10.18 & 8.68 & 6.99 & 8.05 & 3.31 & 4.42 \\
\hline $\mathrm{CaO}$ & 8.88 & 9.90 & 9.55 & 9.76 & 10.02 & 10.82 & 9.81 & 10.48 & 1.22 & 1.58 \\
\hline Na2O & 4.58 & 3.64 & 4.25 & 4.23 & 3.25 & 2.73 & 3.56 & 3.69 & 2.34 & 2.58 \\
\hline K2O & 1.56 & 1.18 & 1.83 & 1.70 & 0.64 & 1.29 & 0.69 & 1.29 & 0.17 & 0.14 \\
\hline P2O5 & 0.599 & 0.490 & 0.494 & 0.566 & 0.227 & 0.471 & 0.282 & 0.524 & 0.37 & 0.52 \\
\hline Sum & 99.39 & 99.81 & 99.33 & 98.44 & 100.02 & 97.85 & 99.99 & 97.97 & 99.18 & 100.64 \\
\hline Mg\# & 53.73 & 64.95 & 57.96 & 58.06 & 64.86 & 60.84 & 54.49 & 57.47 & 64.38 & 63.22 \\
\hline $\mathbf{N i}$ & 92 & 272 & 146 & 156 & 209 & 178 & 136 & 142 & 164 & 214 \\
\hline $\mathrm{Cr}$ & 229 & 317 & 180 & 189 & 480 & 348 & 225 & 381 & & \\
\hline Sc & 20 & 23 & 19 & 19 & 23 & 22 & 25 & 24 & & \\
\hline $\mathbf{V}$ & 201 & 239 & 199 & 222 & 218 & 242 & 229 & 235 & & \\
\hline Ba & 353 & 378 & 543 & 528 & 197 & 380 & 486 & 346 & 295 & 417 \\
\hline $\mathbf{R b}$ & 24 & 21 & 27 & 27 & 9 & 19 & 8 & 22 & & \\
\hline $\mathrm{Sr}$ & 793 & 718 & 904 & 939 & 457 & 958 & 460 & 1012 & 644 & 849 \\
\hline $\mathrm{Zr}$ & 226 & 191 & 229 & 227 & 111 & 190 & 119 & 224 & 167 & 181 \\
\hline $\mathbf{Y}$ & 24 & 22 & 21 & 20 & 18 & 23 & 25 & 22 & 25 & 24 \\
\hline Nb & 83.4 & 72.1 & 82.5 & 86.9 & 29.2 & 76.6 & 27.1 & 87.4 & 71.0 & 84.0 \\
\hline Ga & 19 & 19 & 20 & 22 & 19 & 19 & 21 & 19 & & \\
\hline $\mathbf{C u}$ & 51 & 85 & 64 & 68 & 82 & 60 & 98 & 58 & 70 & 80 \\
\hline Zn & 90 & 91 & 86 & 87 & 91 & 82 & 106 & 96 & 126 & 151 \\
\hline $\mathbf{P b}$ & 2 & 2 & 4 & 2 & 1 & 2 & 2 & 2 & 2 & \\
\hline La & 36 & 44 & 49 & 50 & 15 & 34 & 14 & 35 & & \\
\hline $\mathrm{Ce}$ & 70 & 70 & 82 & 81 & 31 & 68 & 37 & 74 & 71 & 86 \\
\hline Th & 5 & 7 & 7 & 9 & 3 & 6 & 3 & 4 & & \\
\hline Nd & 34 & 28 & 33 & 31 & 18 & 30 & 18 & 33 & & \\
\hline
\end{tabular}


Table 2. Chondrite-normalized Rare Earth Element concentrations for whole rocks, Harrat

\begin{tabular}{lcccccc}
\hline Samples & HH-1 & HH-3 & HH-4 & HH-6 & HH-9 & HH-10 \\
$\mathrm{La}$ & 151.73 & 169.63 & 200.93 & 207.06 & 65.32 & 150.90 \\
$\mathrm{Ce}$ & 119.73 & 115.57 & 134.24 & 137.28 & 49.72 & 110.60 \\
$\mathrm{Pr}$ & 95.58 & 84.67 & 97.75 & 99.90 & 40.22 & 86.55 \\
$\mathrm{Nd}$ & 77.55 & 64.33 & 74.07 & 75.78 & 34.23 & 68.16 \\
$\mathrm{Sm}$ & 49.85 & 39.57 & 45.35 & 45.60 & 25.97 & 43.45 \\
$\mathrm{Eu}$ & 44.08 & 35.95 & 38.15 & 40.35 & 24.46 & 38.17 \\
$\mathrm{Gd}$ & 32.74 & 26.61 & 28.80 & 29.77 & 19.63 & 29.24 \\
$\mathrm{~Tb}$ & 27.37 & 22.19 & 22.78 & 23.75 & 17.27 & 23.94 \\
$\mathrm{Dy}$ & 22.16 & 18.42 & 18.51 & 19.28 & 15.02 & 20.02 \\
$\mathrm{Ho}$ & 18.58 & 15.59 & 15.47 & 15.65 & 12.87 & 16.52 \\
$\mathrm{Er}$ & 15.68 & 13.07 & 12.94 & 12.97 & 11.23 & 13.75 \\
$\mathrm{Tm}$ & 13.94 & 11.54 & 11.34 & 11.19 & 9.76 & 11.82 \\
$\mathrm{Yb}$ & 12.37 & 10.52 & 10.34 & 10.12 & 8.92 & 11.05 \\
$\mathrm{Lu}$ & 11.43 & 10.07 & 9.97 & 9.70 & 8.88 & 10.97 \\
& & & & & & \\
$\mathrm{La} / \mathrm{Yb}$ & 12.27 & 16.13 & 19.43 & 20.46 & 7.32 & 13.65 \\
$\mathrm{Dy} / \mathrm{Yb}$ & 1.79 & 1.75 & 1.79 & 1.91 & 1.68 & 1.81 \\
$\mathrm{La} / \mathrm{Sm}$ & 3.04 & 4.29 & 4.43 & 4.54 & 2.52 & 3.47 \\
$\mathrm{Sm} / \mathrm{Yb}$ & 4.03 & 3.76 & 4.39 & 4.51 & 2.91 & 3.93 \\
$\mathrm{Nb} / \mathrm{Zr}$ & 0.39 & 0.40 & 0.38 & 0.41 & 0.28 & 0.43 \\
$\mathrm{Ce} / \mathrm{Y}$ & 2.78 & 3.14 & 3.79 & 3.88 & 1.72 & 2.90 \\
\hline
\end{tabular}




\section{Hutaymah}

\begin{tabular}{cccc}
\hline HH-11 & HH-12 & $\mathbf{1 7 6 7 0 1}$ & $\mathbf{1 7 6 7 3 4}$ \\
72.68 & 152.83 & 144.34 & 199.75 \\
54.65 & 119.62 & 110.19 & 141.34 \\
45.84 & 94.82 & 86.51 & 105.89 \\
40.16 & 75.52 & 69.57 & 81.87 \\
32.05 & 47.30 & 46.00 & 50.25 \\
30.03 & 42.61 & 39.62 & 42.35 \\
24.56 & 31.43 & 30.80 & 32.09 \\
21.87 & 25.86 & 26.33 & 26.39 \\
19.56 & 20.89 & 21.64 & 21.41 \\
17.35 & 17.53 & 18.41 & 17.85 \\
15.30 & 14.73 & 15.72 & 14.77 \\
13.67 & 12.81 & 14.25 & 13.18 \\
12.20 & 11.40 & 12.48 & 11.79 \\
12.41 & 10.91 & 12.29 & 11.83 \\
& & & \\
5.96 & 13.41 & 11.56 & 16.94 \\
1.60 & 1.83 & 1.73 & 1.82 \\
2.27 & 3.23 & 3.14 & 3.97 \\
2.63 & 4.15 & 3.68 & 4.26 \\
0.24 & 0.41 & 0.43 & 0.46 \\
1.43 & 3.18 & 2.87 & 3.60 \\
\hline
\end{tabular}


Table 3: 40Ar-39Ar Age Determinations for Lava Flows from Harrat Hutaymah, western Saudi Arabia

\begin{tabular}{|c|c|c|c|c|c|c|c|c|c|c|c|c|}
\hline \multirow[t]{2}{*}{ Sample } & \multicolumn{4}{|c|}{ Total Fusior2s erroıPlateau Age2s error } & \multirow[t]{2}{*}{$\mathbf{N}$} & \multicolumn{5}{|c|}{ MSWD sochron Ag(2s error MSWD 40Ar/36Ar } & \multirow{2}{*}{$\begin{array}{c}2 \mathrm{~s} \\
\text { error }\end{array}$} & \multirow[t]{2}{*}{ Comment } \\
\hline & (Ка) & (Ka) & (Ka) & (Ka) & & & (Ka) & (Ka) & & initial & & \\
\hline $\mathrm{HH}-1$ & 246 & 138 & 259 & 120 & $16 / 16$ & 0.51 & 351 & 193 & 0.51 & 295 & 1 & \\
\hline $\mathrm{HH}-3$ & 2340 & 1070 & 2630 & 590 & $16 / 16$ & 1.46 & 2370 & 980 & 1.54 & 296 & 2 & excess $40 \mathrm{Ar}$ \\
\hline $\mathrm{HH}-4$ & 2650 & 580 & 2650 & 940 & $16 / 16$ & 3.12 & 1900 & 980 & 2.19 & 300 & 4 & excess $40 \mathrm{Ar}$ \\
\hline HH-6 & 857 & 474 & 729 & 266 & $12 / 16$ & 1.22 & 1009 & 525 & 1.29 & 295 & 2 & \\
\hline $\mathrm{HH}-9$ & 471 & 161 & 436 & 97 & $14 / 16$ & 0.69 & 497 & 160 & 0.69 & 295 & 1 & \\
\hline $\mathrm{HH}-10$ & 704 & 48 & 709 & 62 & $16 / 16$ & 2.14 & 712 & 131 & 2.26 & 296 & 3 & \\
\hline $\mathrm{HH}-11$ & 832 & 39 & 844 & 44 & $14 / 16$ & 1.65 & 785 & 115 & 1.64 & 297 & 2 & \\
\hline $\mathrm{HH}-12$ & 581 & 125 & 630 & 82 & $33 / 33$ & 1.30 & 833 & 162 & 1.15 & 294 & 1 & \\
\hline 176688 & 436 & 617 & 955 & 545 & $13 / 17$ & 0.23 & 18 & 1453 & 0.08 & 298 & 3 & \\
\hline 176691 & 1140 & 8 & 1085 & 103 & $19 / 31$ & 47.10 & 818 & 37 & 1.82 & 340 & 5 & excess $40 \mathrm{Ar}$ \\
\hline $176701 a$ & 826 & 207 & 818 & 203 & $17 / 17$ & 0.54 & 431 & 290 & 0.40 & 298 & 3 & \\
\hline $176701 b$ & 2339 & 25 & 1765 & 255 & $31 / 31$ & $>100$ & 893 & 44 & 1.72 & 331 & 1 & excess $40 \mathrm{Ar}$ \\
\hline $176710 a$ & 4290 & 480 & 2100 & 910 & $8 / 16$ & 6.16 & 1380 & 890 & 6.17 & 297 & 3 & excess $40 \mathrm{Ar}$ \\
\hline $176710 \mathrm{~b}$ & 980 & 9 & 848 & 8 & $14 / 31$ & 0.43 & 838 & 25 & 0.40 & 302 & 14 & \\
\hline 176712 & 8040 & 590 & 4580 & 1750 & $11 / 17$ & 16.58 & 550 & 460 & 0.40 & 304 & 1 & excess $40 \mathrm{Ar}$ \\
\hline 176734a & 930 & 114 & 868 & 90 & $16 / 17$ & 0.46 & 703 & 175 & 0.16 & 298 & 2 & \\
\hline $176734 b$ & 881 & 9 & 804 & 10 & $19 / 30$ & 1.54 & 784 & 19 & 1.22 & 307 & 10 & \\
\hline
\end{tabular}

Ages calculated using sanidine monitor FCs (28.201 Ma) and the total decay constant $\square=5.530 \mathrm{E}-10 / \mathrm{yr}$. N is the number of heating steps (defining plateau/total); MSWD is an F-statistic that compares the variance within step ages with the variance about the plateau age. Preferred ages are shown in bold; italics indicate sample with suspected mantle-derived (excess) 40Ar. 
Table 4. Parental Magma for Harrat Hutaymah Lavas

\begin{tabular}{|l|r|r|}
\hline Oxide, Element & $\begin{array}{l}\text { This Paper } \\
\text { Wt\%, ppm }\end{array}$ & $\begin{array}{l}\text { HPM } \\
\text { Wt\%, }\end{array}$ \\
\hline $\mathrm{SiO} 2$ & 45.5 & 45.5 \\
$\mathrm{Al} 2 \mathrm{O} 3$ & 13.1 & 12.6 \\
$\mathrm{FeO}$ & 10.9 & 10.8 \\
$\mathrm{CaO}$ & 9.9 & 10.0 \\
$\mathrm{MgO}$ & 13.4 & 13.9 \\
$\mathrm{Na2O}$ & 3.3 & 3.2 \\
$\mathrm{~K} 2 \mathrm{O}$ & 1.0 & 1.0 \\
$\mathrm{TiO} 2$ & 2.1 & 2.0 \\
$\mathrm{MnO}$ & 0.2 & 0.2 \\
$\mathrm{P} 2 \mathrm{O} 5$ & 0.4 & 0.5 \\
$\mathrm{Cr}$ & 700 & \\
$\mathrm{Ni}$ & 500 & 570 \\
$\mathrm{Mg} \#$ & & \\
& 0.713 & 0.721 \\
\hline
\end{tabular}

HPM is an average of 8 most MgO-rich lavas (Thornber, 1992) 


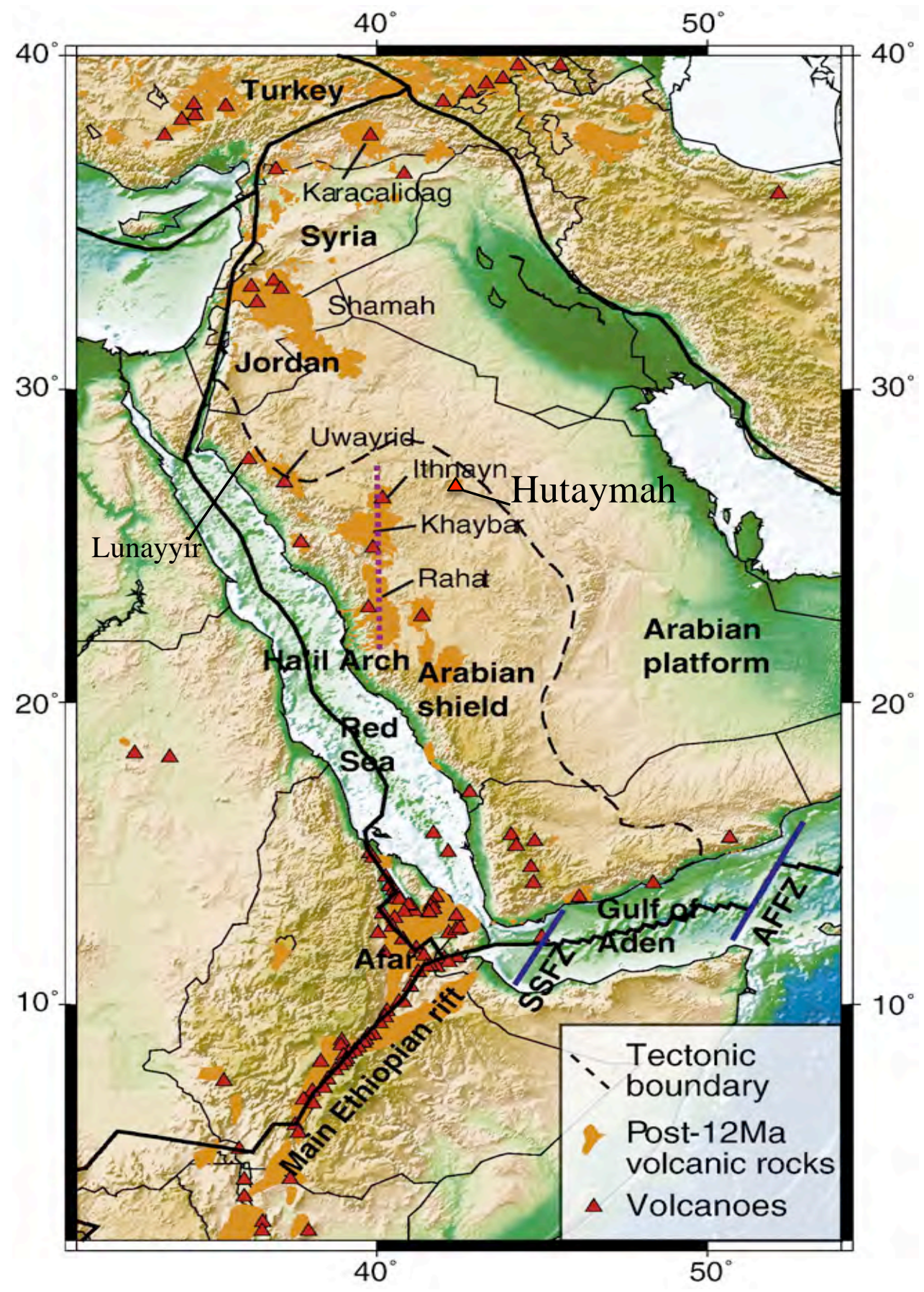

Figure 1. 
Figure 2

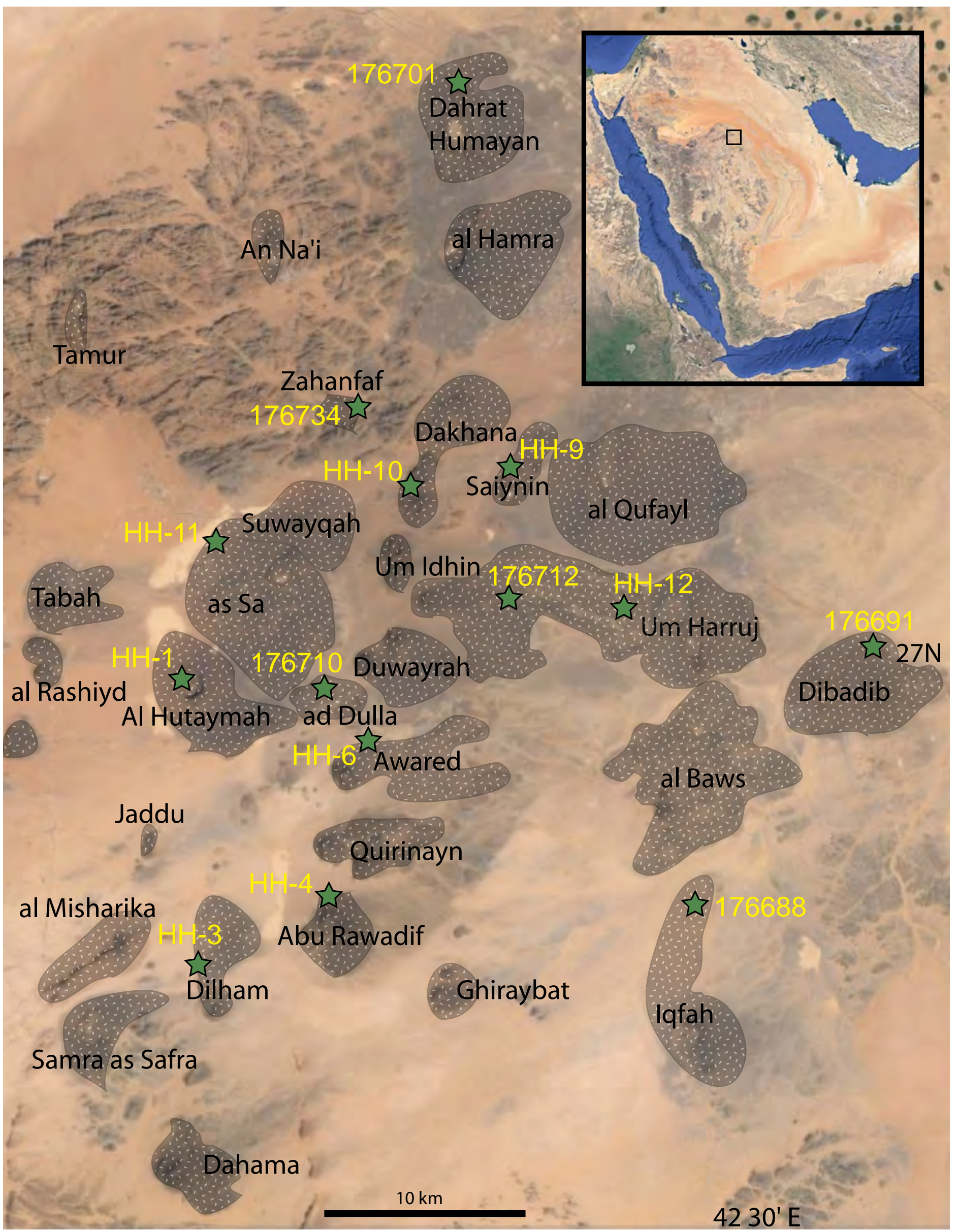



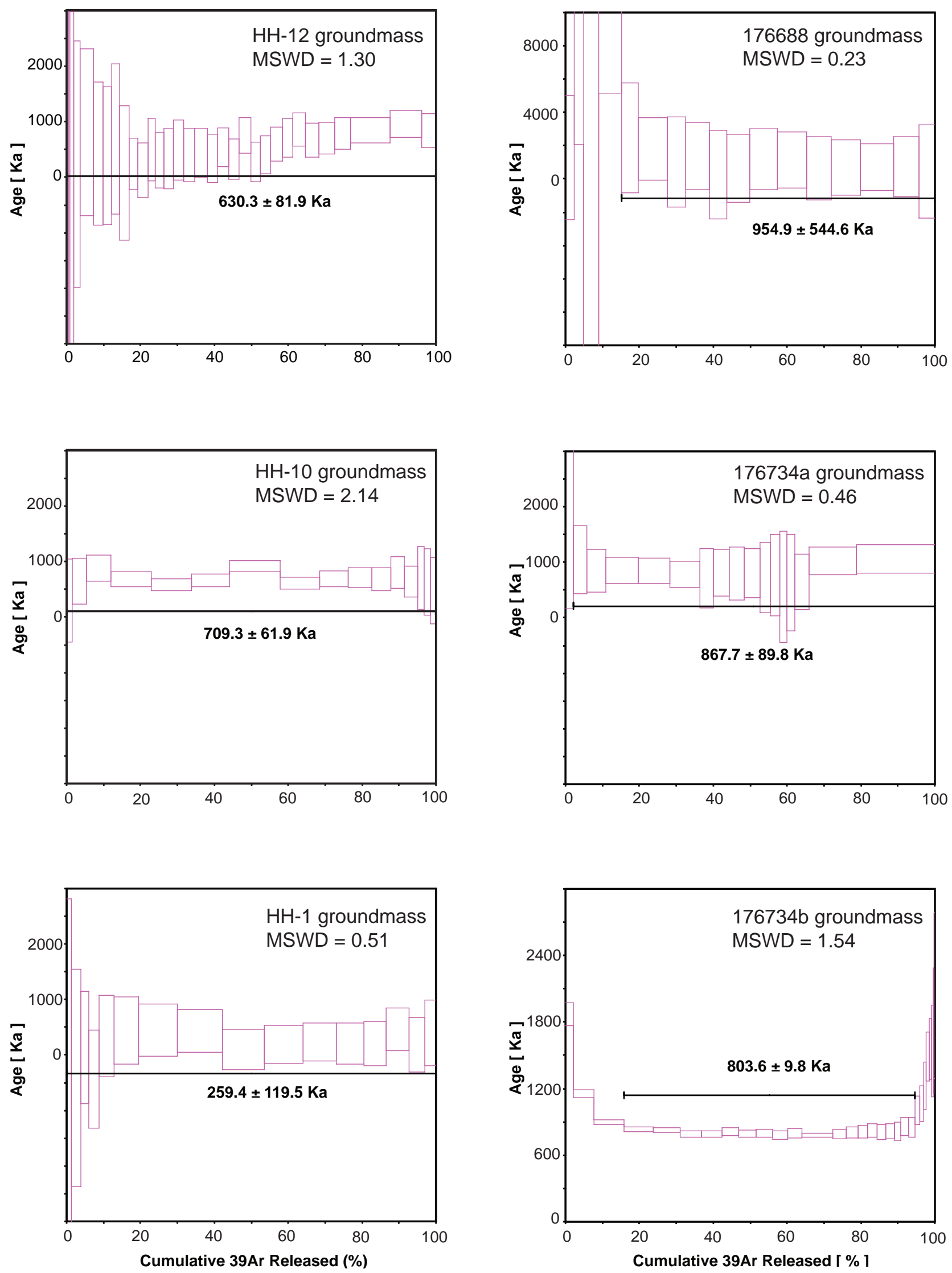

Figure $3 a$ 

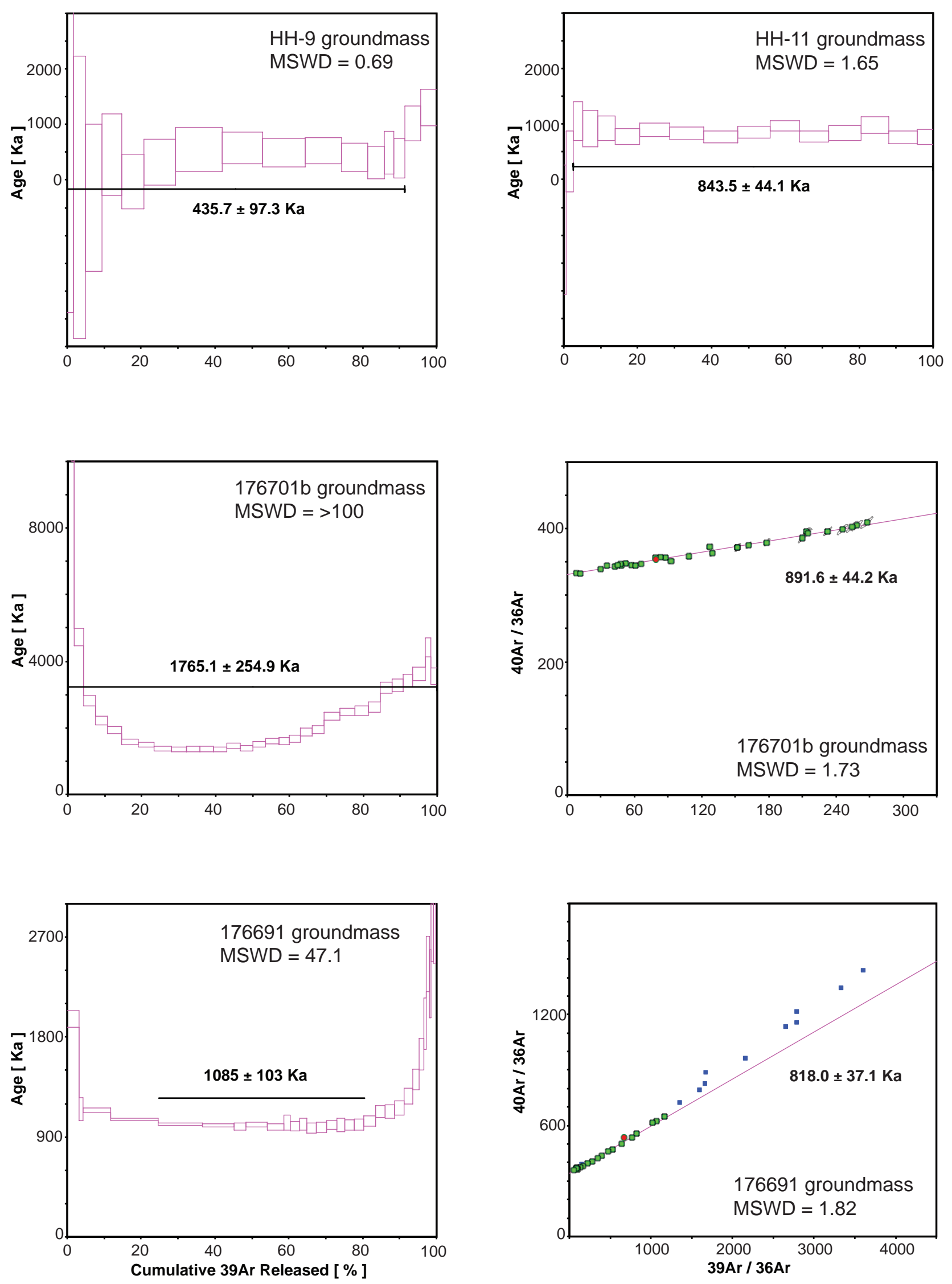

Figure $3 b$ 

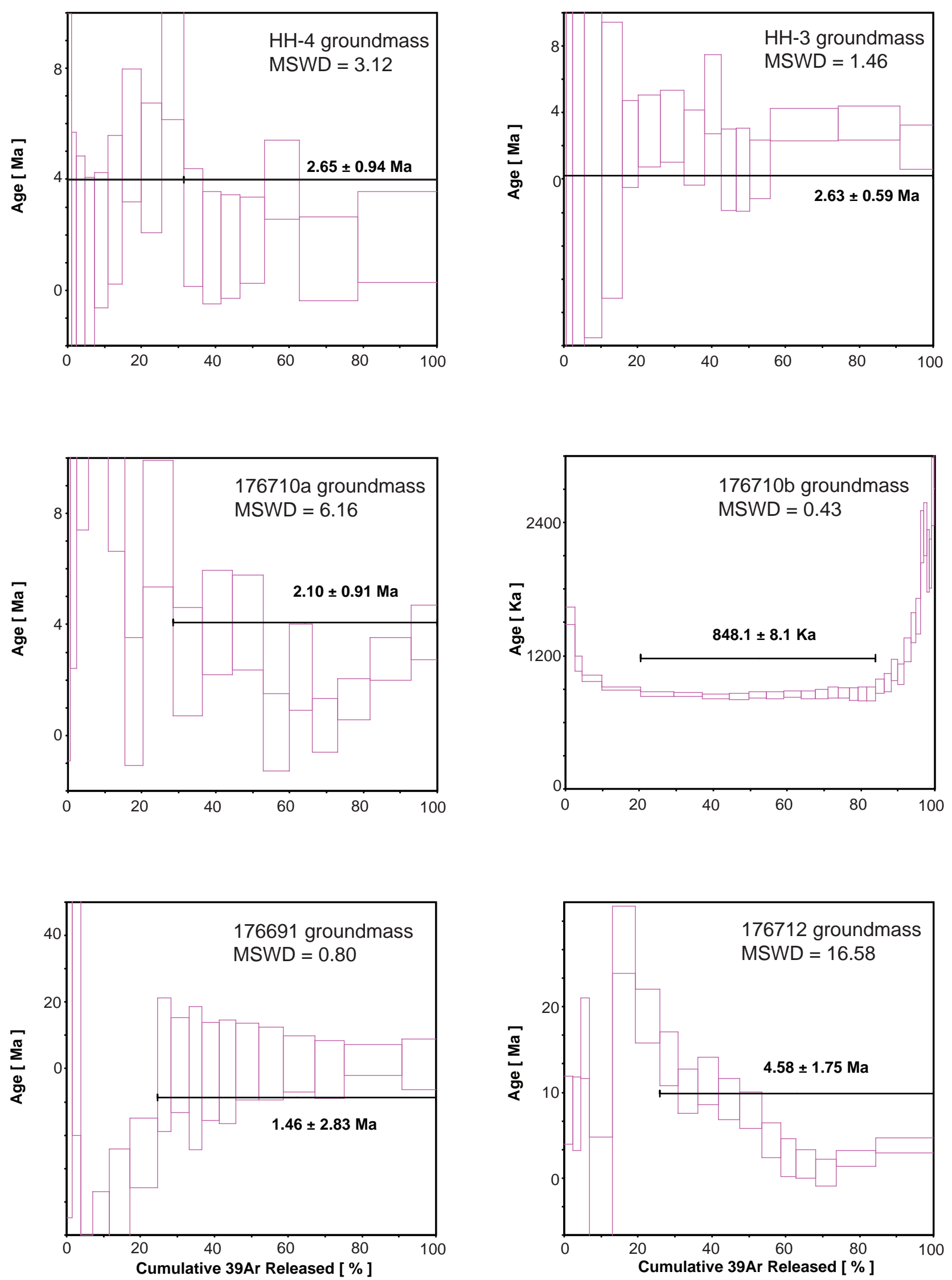

Figure $3 c$ 

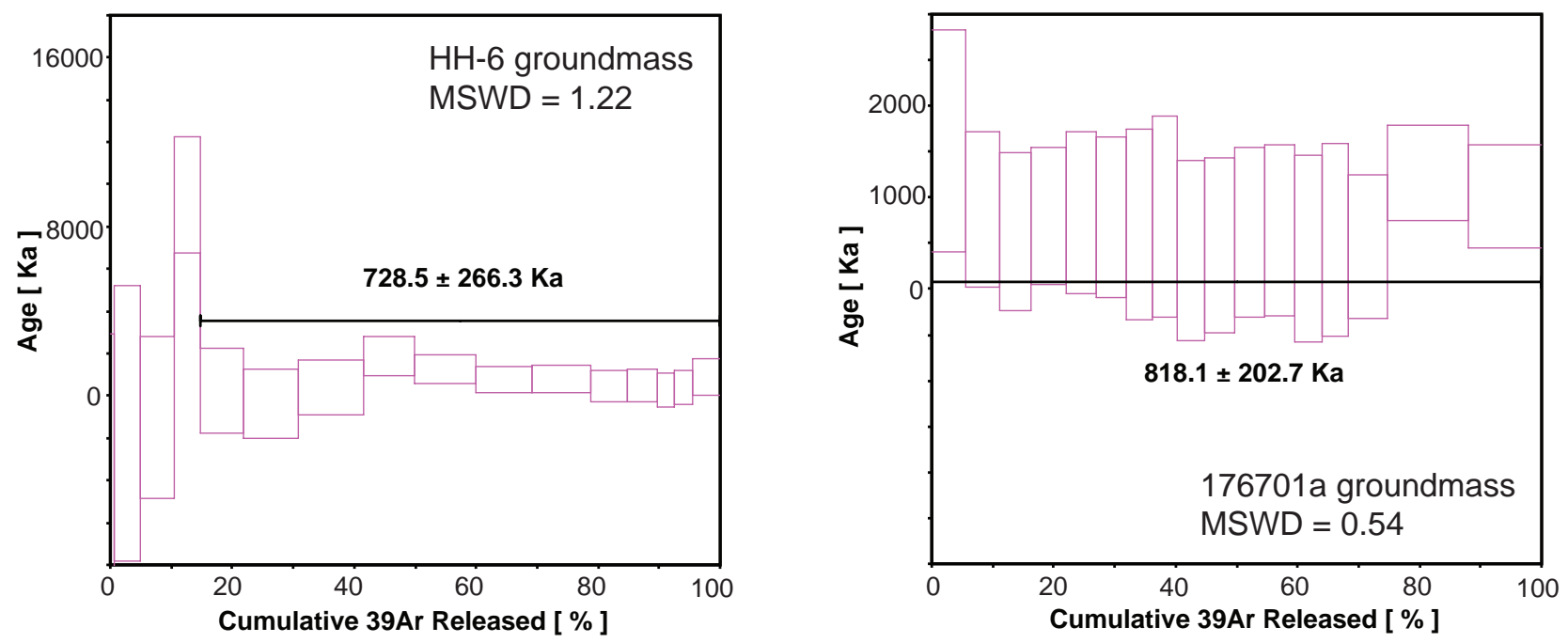

Figure 3d 
Figure 4

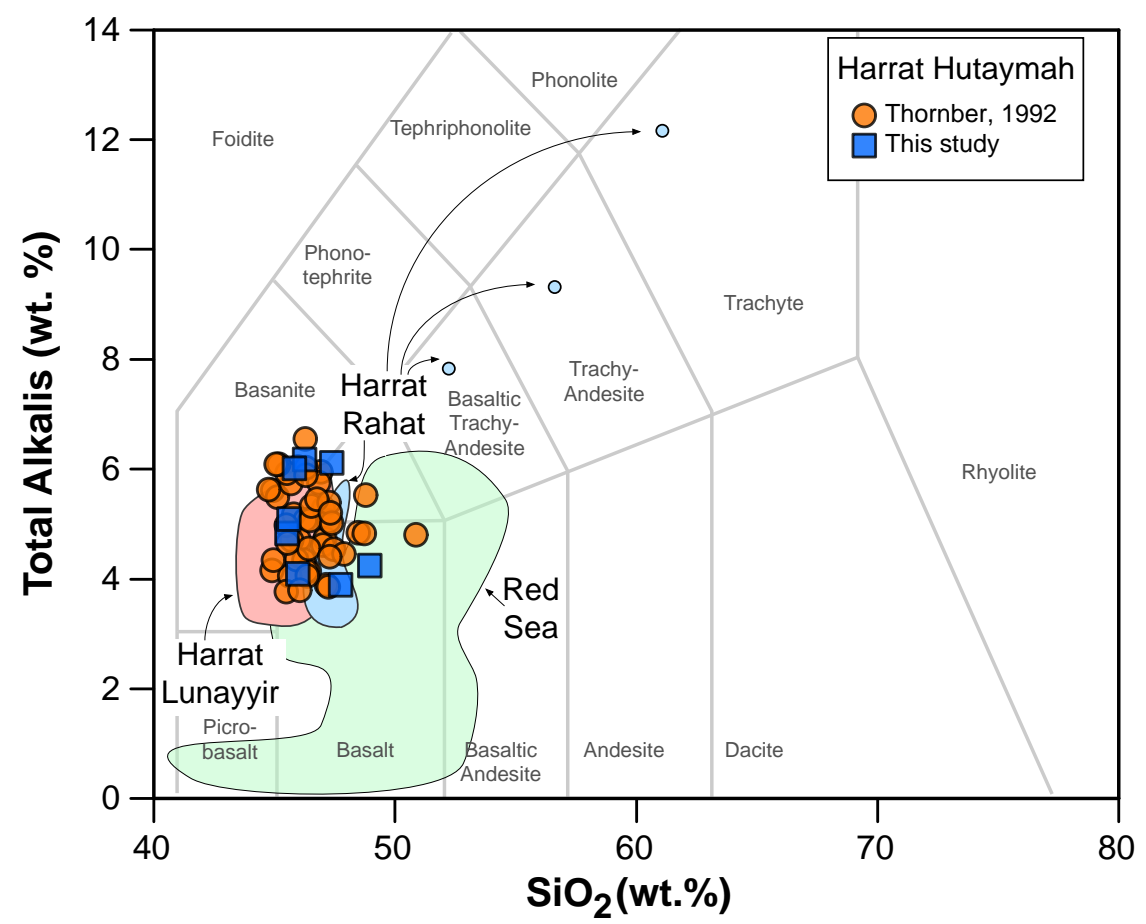


Figure 5
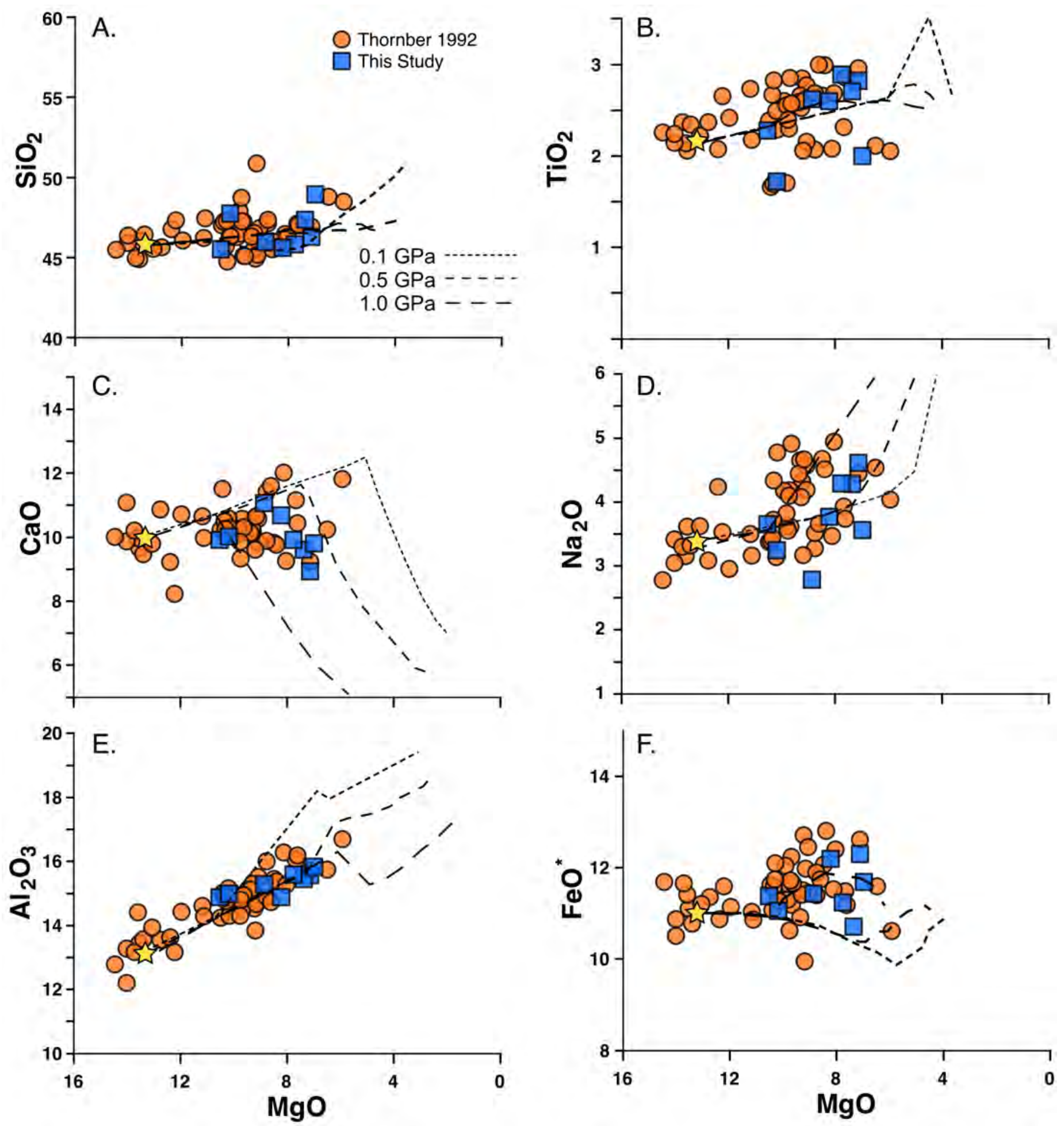
Figure6
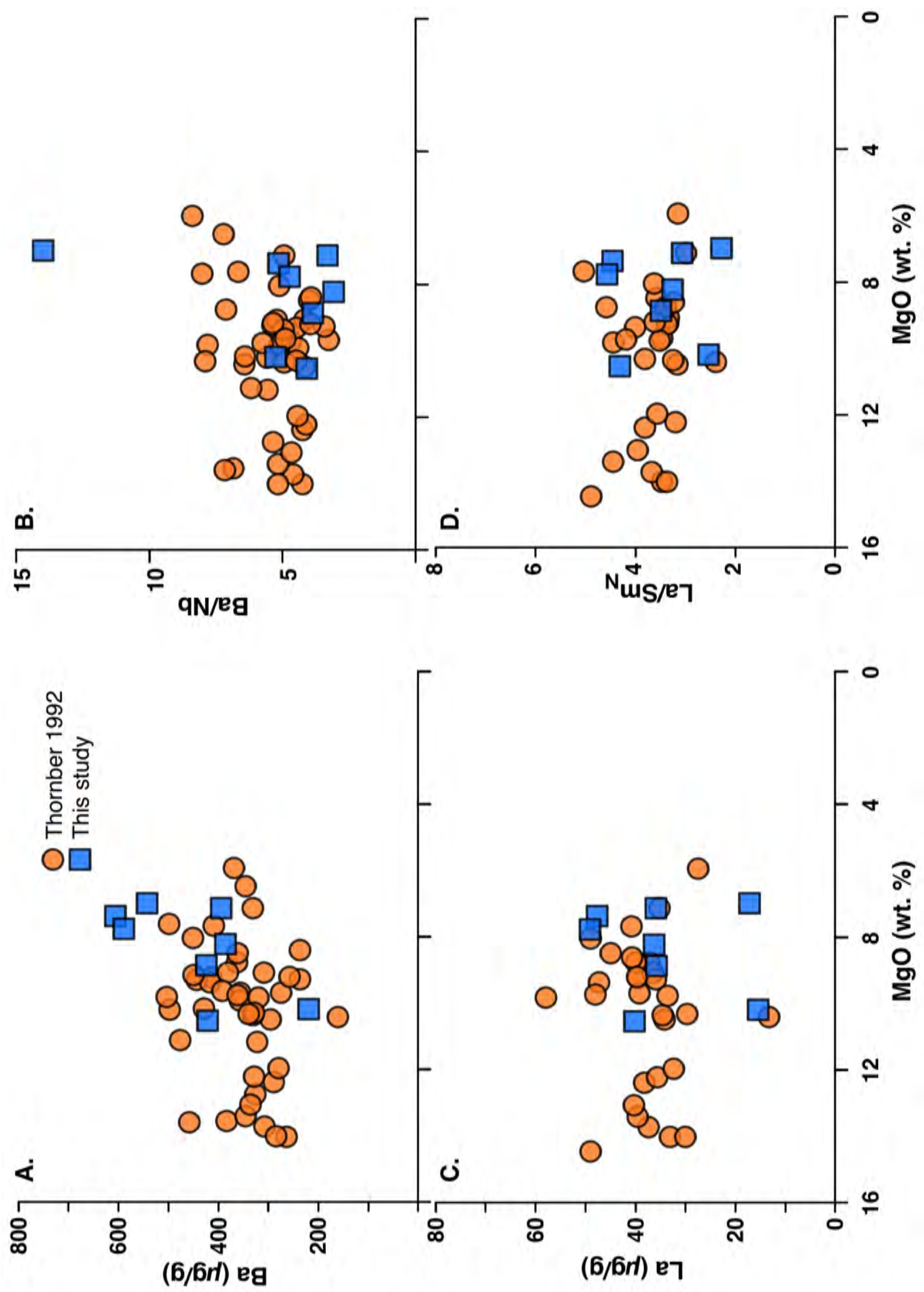


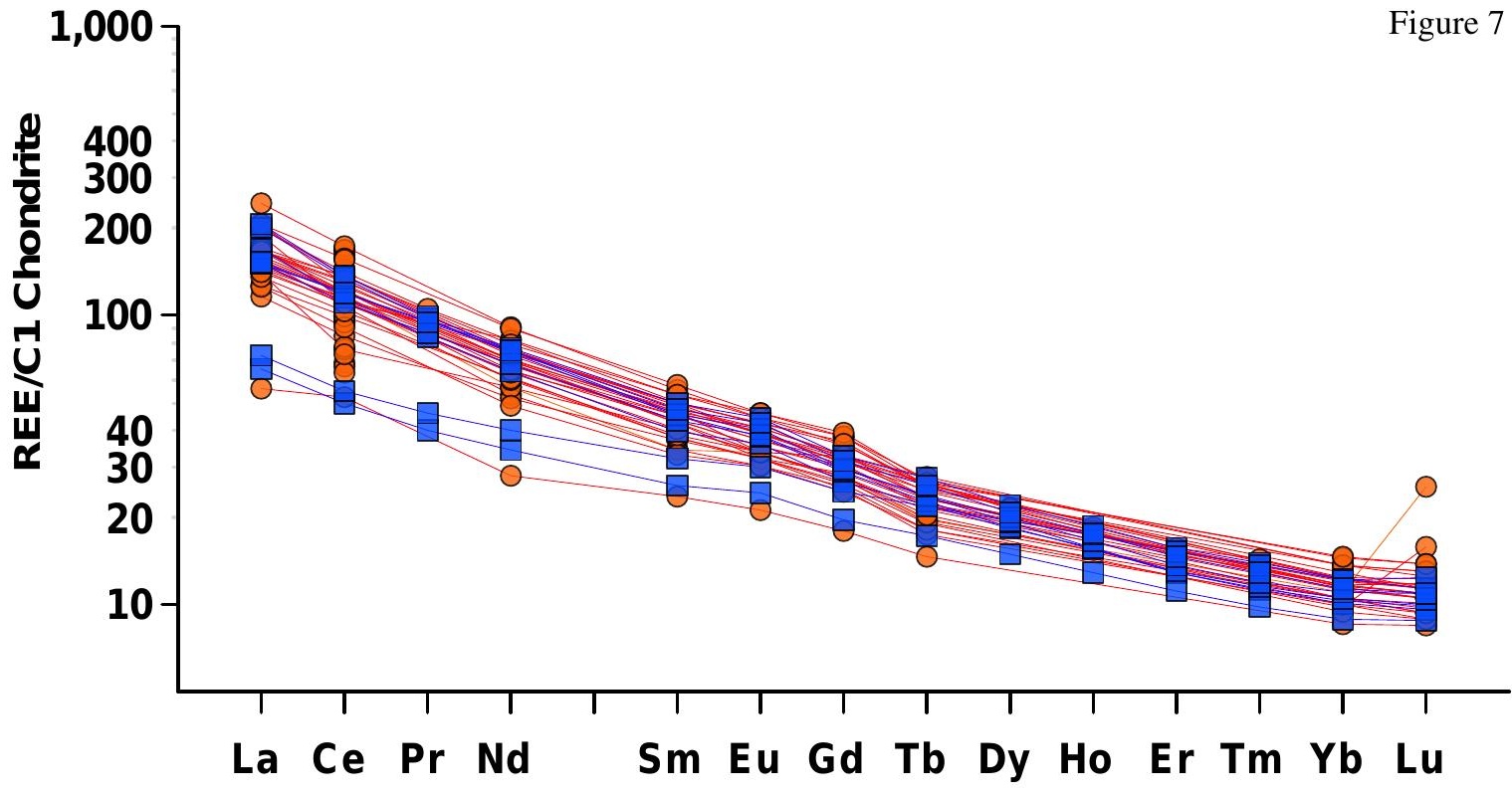




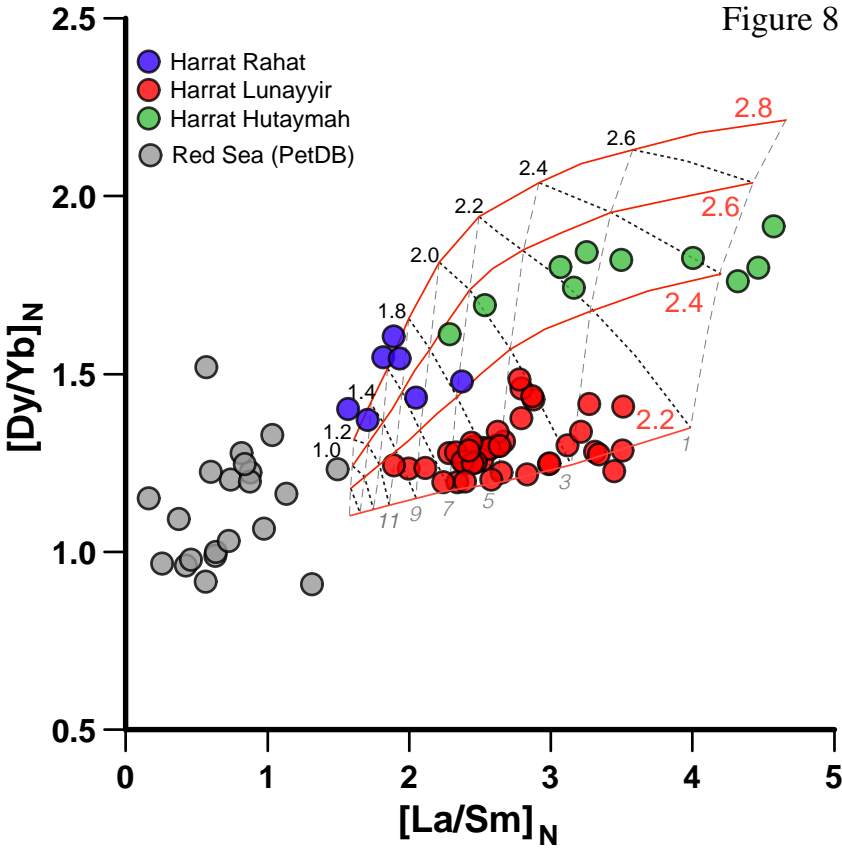


Figure 9

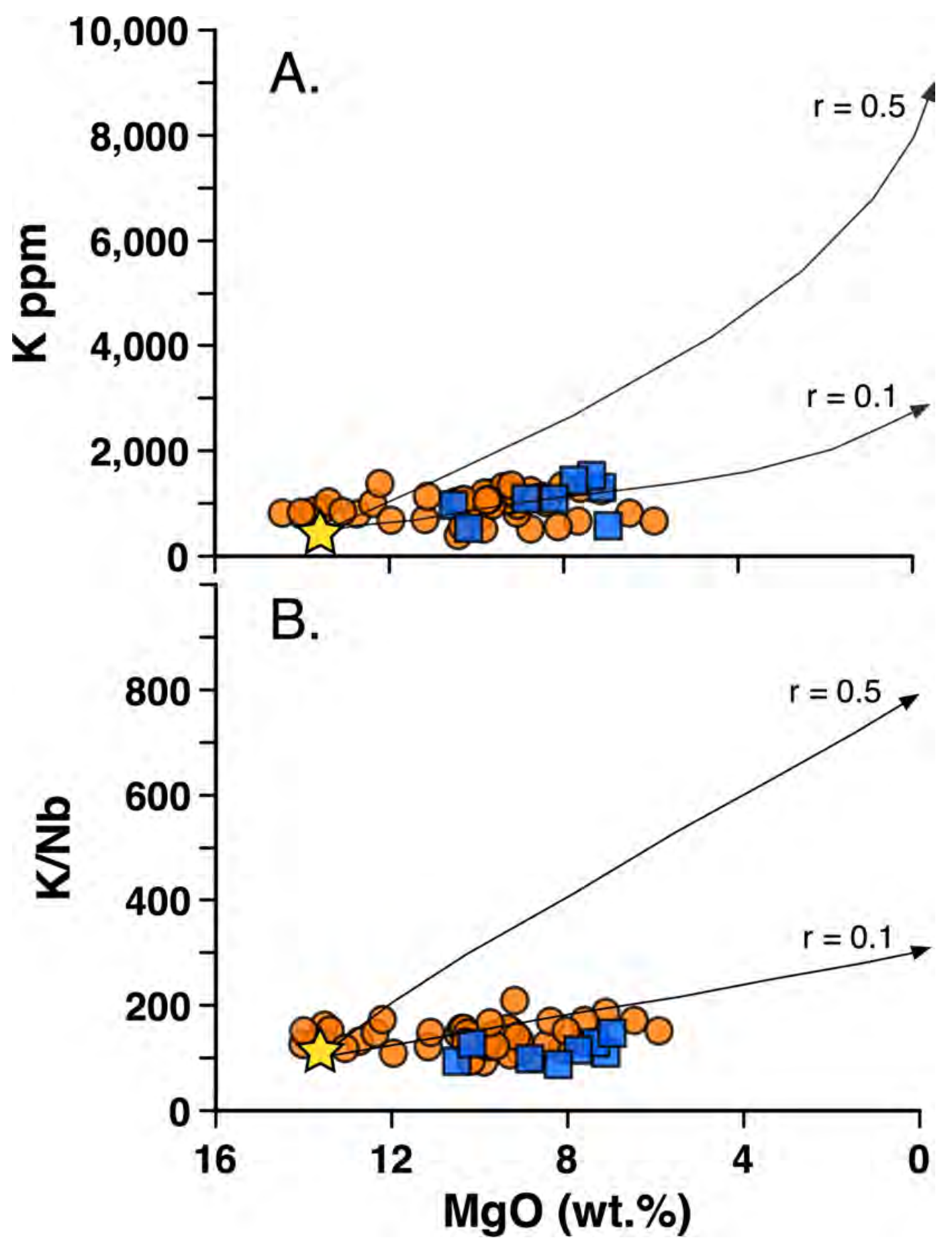

Figure 9. 
Figure 10

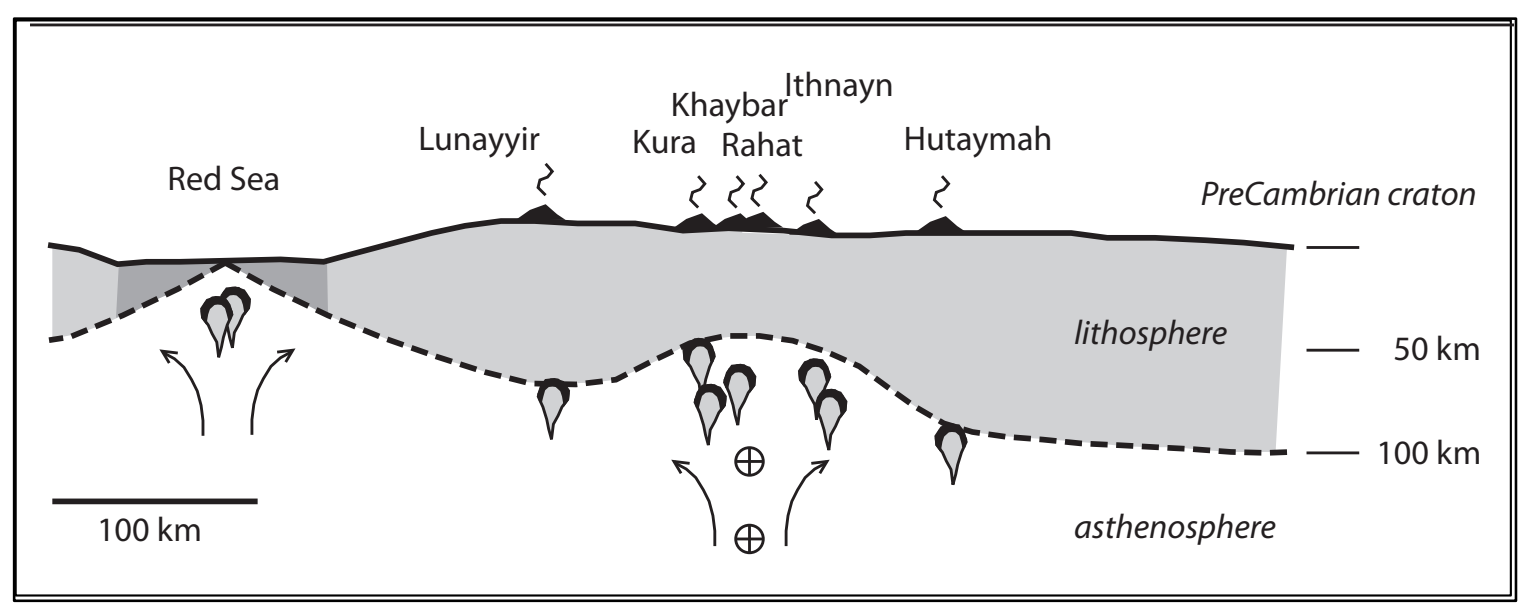

Figure 11. 